\title{
The Late Paleoindian Occupation of the Western Ouachita Mountains of Southeast Oklahoma: The Archaeology of Component V at the Quince Site (34AT134)
}

Timothy K. Perttula

Heritage Research Center, Stephen F. Austin State University

Follow this and additional works at: https://scholarworks.sfasu.edu/ita

Part of the American Material Culture Commons, Archaeological Anthropology Commons, Environmental Studies Commons, Other American Studies Commons, Other Arts and Humanities Commons, Other History of Art, Architecture, and Archaeology Commons, and the United States History Commons

Tell us how this article helped you.

This Article is brought to you for free and open access by the Center for Regional Heritage Research at SFA ScholarWorks. It has been accepted for inclusion in Index of Texas Archaeology: Open Access Gray Literature from the Lone Star State by an authorized editor of SFA ScholarWorks. For more information, please contact cdsscholarworks@sfasu.edu. 


\section{The Late Paleoindian Occupation of the Western Ouachita Mountains of}

Southeast Oklahoma: The Archaeology of Component V at the Quince Site (34AT134)

Creative Commons License

(c) $(1)$ (9)

This work is licensed under a Creative Commons Attribution-NonCommercial 4.0 International License 


\title{
The Late Paleoindian Occupation of the Western Ouachita Mountains of Southeast Oklahoma: The Archaeology of Component V at the Quince Site (34AT134)
}

\author{
Timothy K. Perttula
}

\section{INTRODUCTION}

The Quince site (34AT134) is a well-preserved and relatively deeply stratified Ouachita Mountains archaeological site in Atoka County in southeastern Oklahoma. The site's archaeological deposits are buried in Late Pleistocene and Holocene alluvial terrace deposits of McGee Creek, a tributary to Muddy Boggy Creek, itself a southern-flowing tributary to the Red River, that cuts through the western edge of the mountains (Figure 1).

Excavated in 1982 and 1983 prior to the creation of McGee Creek Reservoir by the Bureau of Reclamation (Ferring 1994), the $3.0 \mathrm{~m}$ deep archaeological deposits at the Quince site contained a record of prehistoric occupations spanning most of the Holocene period (from ca. 10,500 B.P to 1000 radiocarbon years B.P., or ca. 12,590 to 927 calibrated years B.P., see Reimer et al. 2004). Woodland (Component I), Late Archaic (Components II and III), and Middle Archaic (Component IV) period occupational deposits are present in good stratigraphic order within the upper $1 \mathrm{~m}$ of McGee Creek alluvium (Perttula 2014). There are also a series of buried Late Paleoindian occupations (in what is defined as Component V) with features and chipped stone lithic tools recovered in situ that are recognized beginning from about $1.10 \mathrm{~m}$ to $3.0 \mathrm{~m}$ in depth below the surface. In this article, I discuss the archaeological evidence for use of the Western Ouachita Mountains by Late Paleoindian foragers as seen principally from the micro-scale; that is, from the perspective of this one well-preserved and stratified Late Paleoindian site (see overall summaries of the archaeological investigations at the Quince site in Perttula [1984, 1985, 1994, 2007, 2014], and Perttula et al. [1983]).

Paleoindian occupations with good stratigraphic context are apparently quite rare in the Ouachita Mountains and along the edge of the Southeastern woodlands and the Great Plains in the eastern and eastcentral part of the state of Oklahoma (Ballenger 1998, 2001; Galm and Hofman 1984; Story 1990; Wyckoff 1968, 1984, 1999, 2005a; Wyckoff and Bartlett 1995). Much of the archaeological research dealing with Late Paleoindian peoples in this region has dealt primarily with the description and classification of isolated temporally diagnostic projectile points (and the kinds of lithic raw materials employed in projectile point manufacture) found on the surface or in mixed and relatively shallow stratigraphic contexts (cf. Ballenger 1998, 2001; Wyckoff 2005a; Wyckoff and Bartlett 1995). The Quince site Late Paleoindian archaeological deposits provide direct and compelling evidence for the long-term and recurrent use of the western Ouachita Mountains by hunter-gatherer groups. ${ }^{1}$

\section{PALEOINDIAN ENVIRONMENTAL CONTEXT}

There have been substantial paleoenvironmental changes in the McGee Creek area over the last 12,000 years, based primarily on Core VI pollen data from Ferndale Bog, only a few miles from Quince at the headwaters of a small tributary to Little Bugaboo Creek (Holloway 1994). Over 11,800 years ago (ca. 13,690 calibrated years ago), the area was an Oak Woodland, but by ca. 11,000 years B.P. (ca. 12,900 calibrated years 


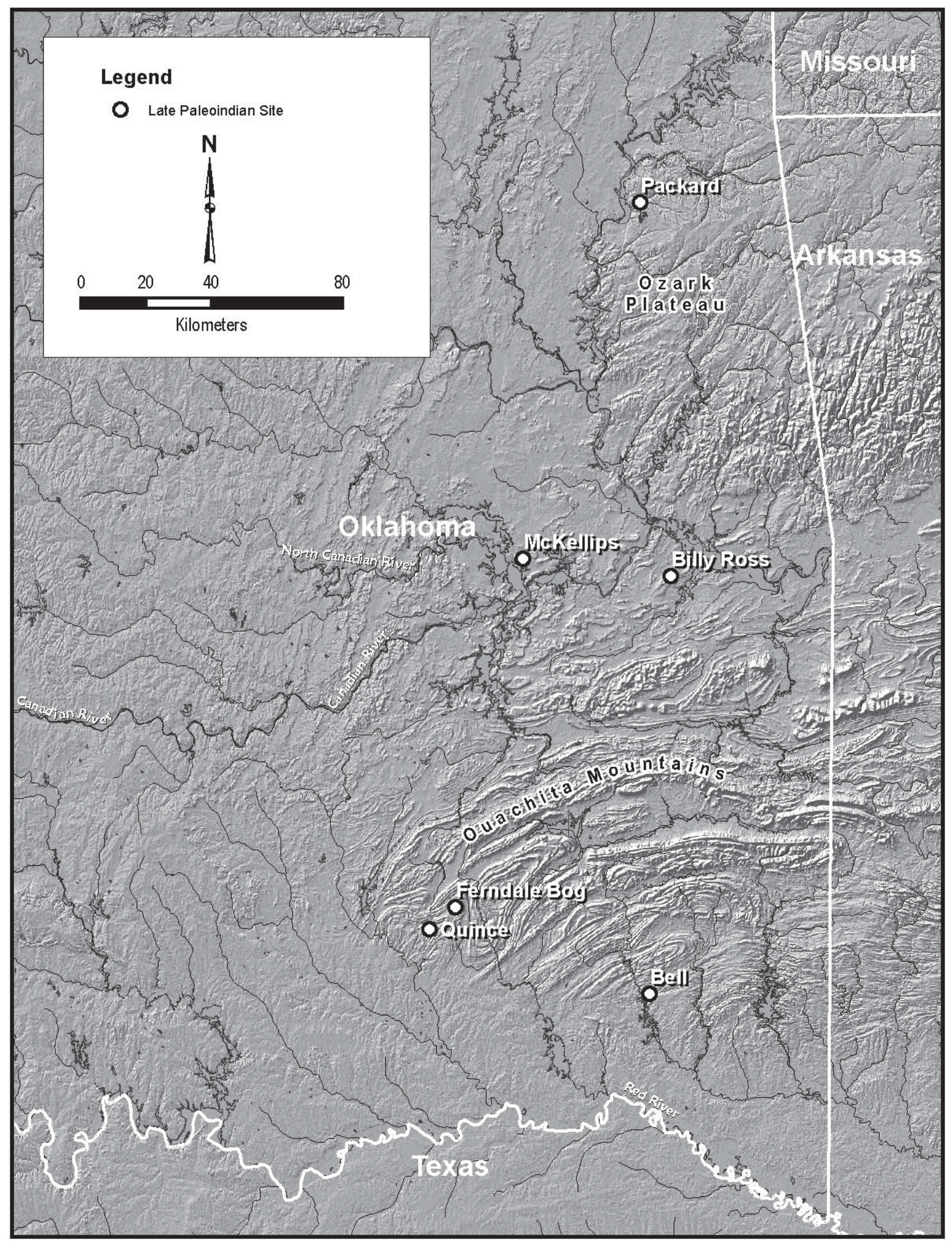

Figure 1. The location of the Quince site, Ferndale Bog, and other Late Paleoindian sites in the Ouachita Mountains, Arkoma Basin, and Ozark Highlands of eastern Oklahoma. 


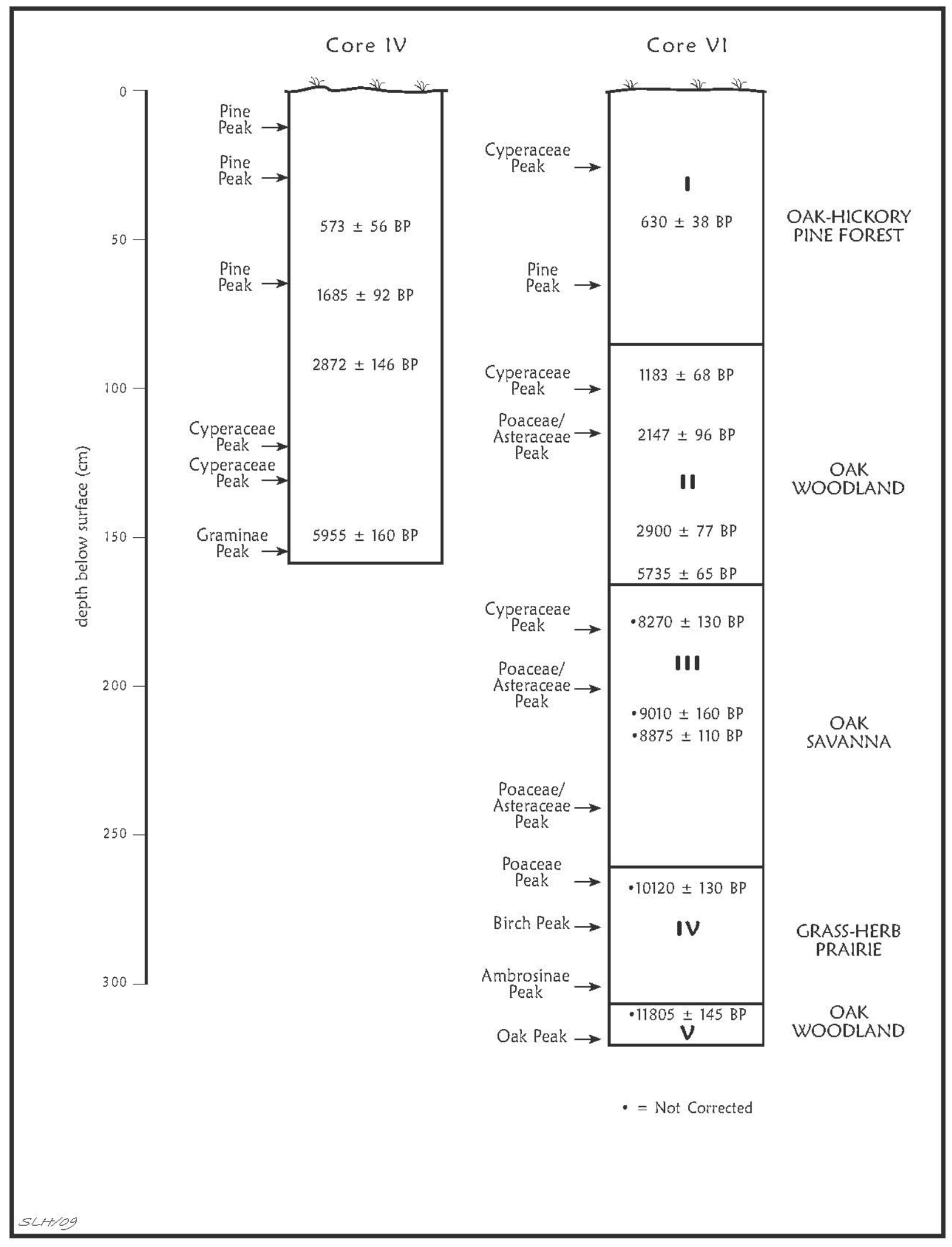

Figure 2. Core VI pollen and paleoenvironmental record, Ferndale Bog (after Holloway 1994 and Albert 1981). 
B.P.), vegetation in the western Ouachita Mountains was dominated by a grass-herb prairie and a limited arboreal (probably riparian) overstory (Figure 2), and the region was likely dry and cold at the onset of the Younger Dryas period (Anderson 2001:155-156). This vegetational community lasted until about 10,000 years B.P. (11,400 calibrated years B.P.), when oak began invading the grasslands in the region. A relatively dry oak savanna replaced the grasslands, marking a warm and drying trend, and this biotic community continued to dominate the region until about 6000 years ago (ca. 6850 calibrated years B.P.).

The Late Paleoindian period has been characterized as a period of time where paleoenvironmental conditions "probably had a major impact on local cultures" (Anderson 2001:155), as well as a time when "Native Americans experimented with various ways of coping with altering environmental conditions in terms of subsistence, stone-tool designs and settlement/mobility patterns" (Bousman et al. 2002:989). During most of the Paleoindian occupation of the Quince site, estimated to have occurred between ca. 10,500-9800 years ago (Goodyear 1982; Wyckoff 1985, 1989; Lopinot et al. 2005), the forest-prairie ecotone was certainly some distance east of the McGee Creek area (cf. Jennings 2008:Figure 7). Thus, prairie resources-bison and other grassland species - may well have been more important locally to Late Paleoindian groups that foraged in the western Ouachita Mountains during certain seasons of the year than were forest resources. The addition of oak in the vegetational communities around Ferndale Bog and the McGee Creek valley during the latter part of the Paleoindian occupation at the Quince site (see Figure 2) would have increased edge habitats, however, that would have been favored by woodland species such as white-tailed deer, and this paleoenvironmental change would have provided more abundant arboreal resources (nuts, seeds, and fruits) for foragers to exploit.

\section{LOCAL SETTING AND STRATIGRAPHY}

The site covers about 2.3 hectares (about 5.8 acres) of alluvial terrace deposits paralleling McGee Creek (Figure 3), a Ouachita Mountains stream that drains south into Muddy Boggy Creek, a tributary of the Red River. The terrace surface stands 6-15 m above the current McGee Creek channel, and drops steeply on the west to the floodplain (Figure 4). Although the site had been timbered over the years, it had never been plowed.

Excavations over two field seasons at the Quince site took place in a 14 x $11 \mathrm{~m}$ block of contiguous 1 $\mathrm{x} 1 \mathrm{~m}$ units in the southwestern part of the site (Figure 5), in an area where test excavations had shown that there were deep alluvial deposits with archaeological remains (McGuff 1993), and near a possible salt lick. The surface elevation across the block ranged from 1150-1190 cm below an arbitrary datum (Figure 6). The entire block was carried to a common depth of approximately $140 \mathrm{~cm}$ bs (through Occupation Horizon 10), with increasingly smaller blocks to ca. $155 \mathrm{~cm}$ bs. Below that depth, only a series of $1 \mathrm{x} 1 \mathrm{~m}$ units within the block were eventually excavated to between $210-300 \mathrm{~cm}$ bs.

The Paleoindian archaeological deposits at Quince are contained in sandy loam to sandy clay loam sediments (zones V-VI) separated by relatively thick illuvial clay lamallae (Figure 7a-b). This Early Holocene alluvium was apparently truncated, then overlain by later Holocene loamy sand alluvium (Zones I-IV) of the "Red Terrace" (Ferring 1994:Figure 5.4c). This alluvium contains stratified Middle Archaic, Late Archaic, and Woodland archaeological deposits (Perttula 1994, 2014).

\section{OCCUPATION HORIZONS}

Using three-dimensional block and grid coordinates and elevation data on burned rocks, features, and lithic tools found in place in the excavations, as well as soil stratigraphic information, 14 separate occupation horizons were defined in the 3+ $\mathrm{m}$ thick archaeological deposits at Quince; six of the occupation horizons are in the Late Paleoindian component in alluvial Zones V and VI (see Figure 7a-b). By "occupation horizon," I mean a composite of occupational episodes (i.e., Binford 1983:367), as best as can be determined, 


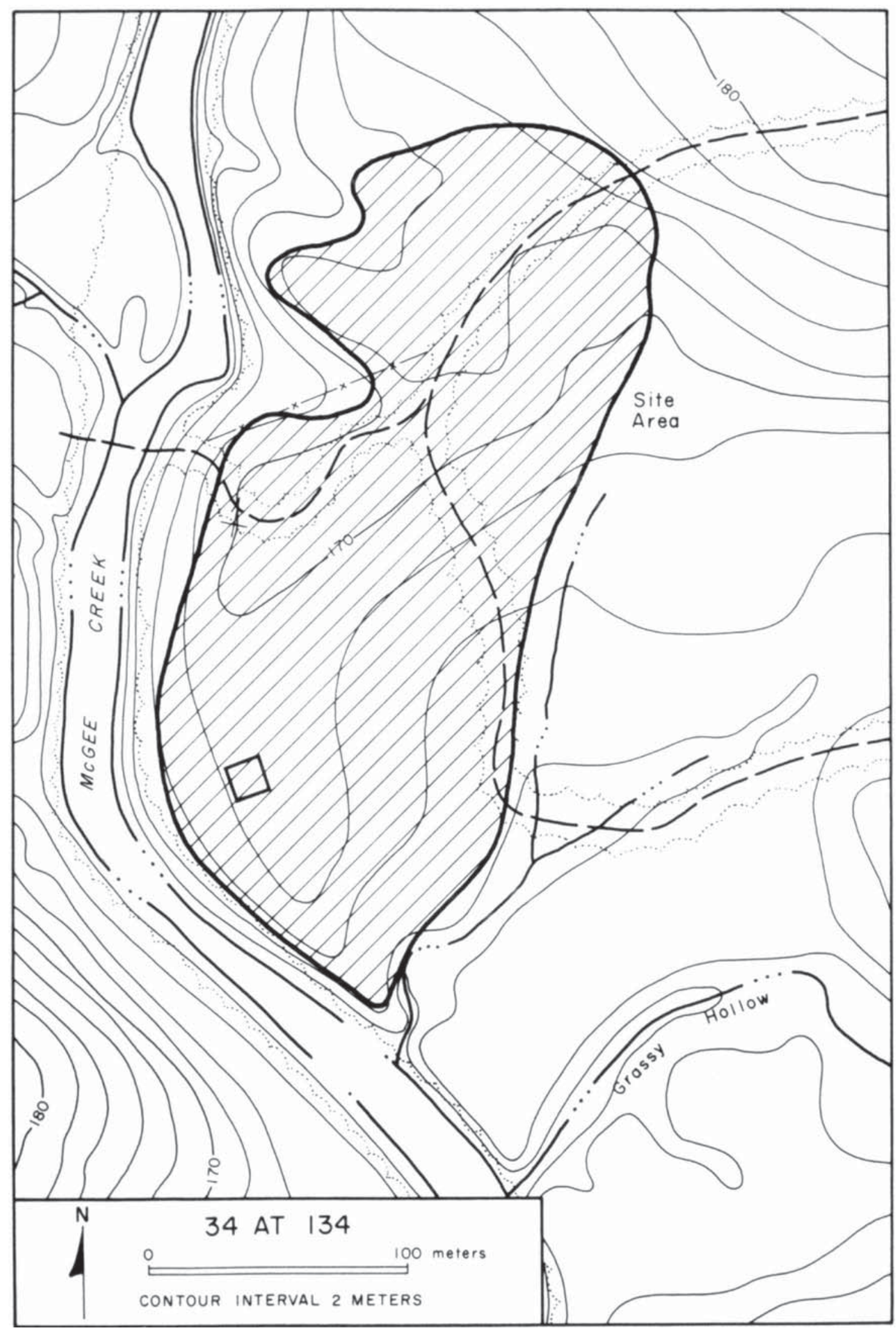

Figure 3. Map of the Quince site. 


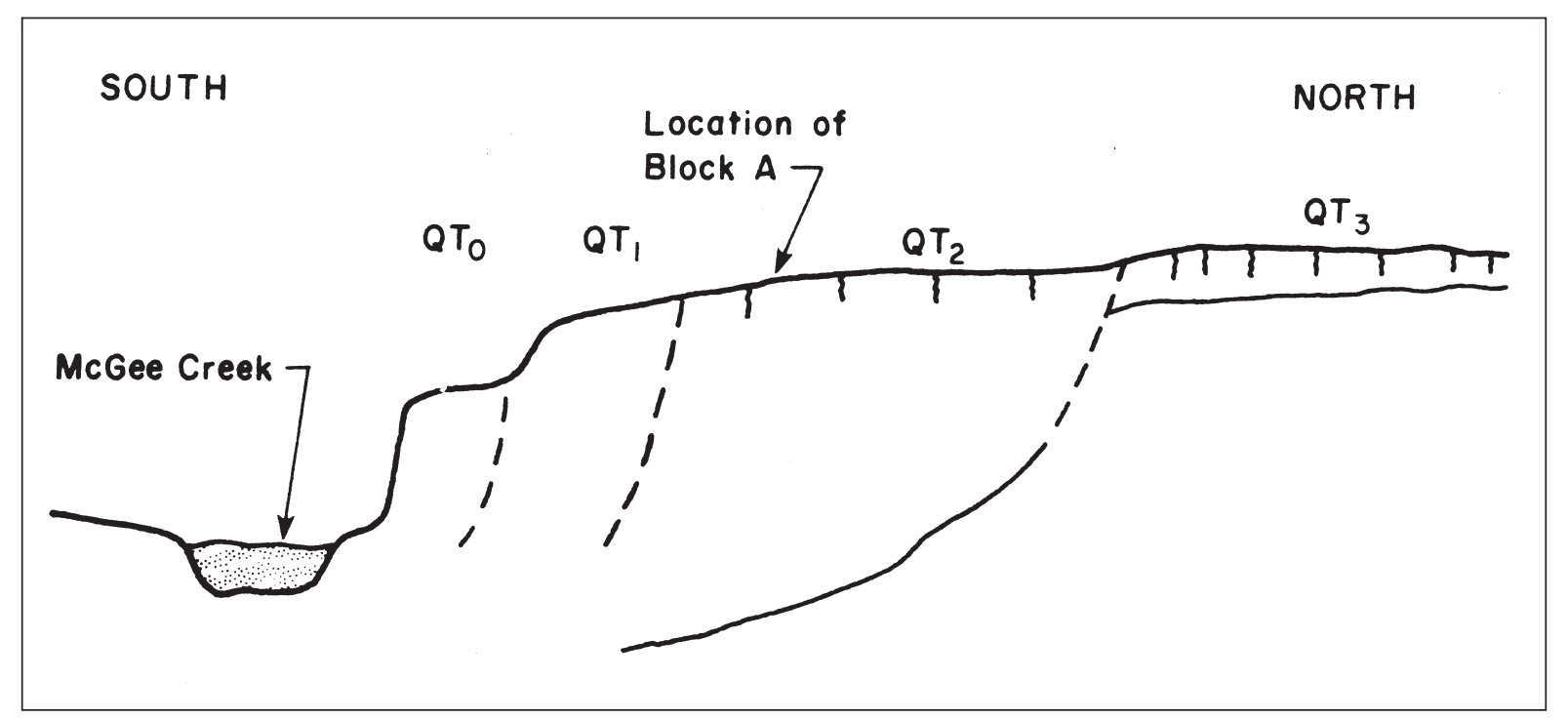

Figure 4. Schematic cross-section of the Quince site alluvial deposits.

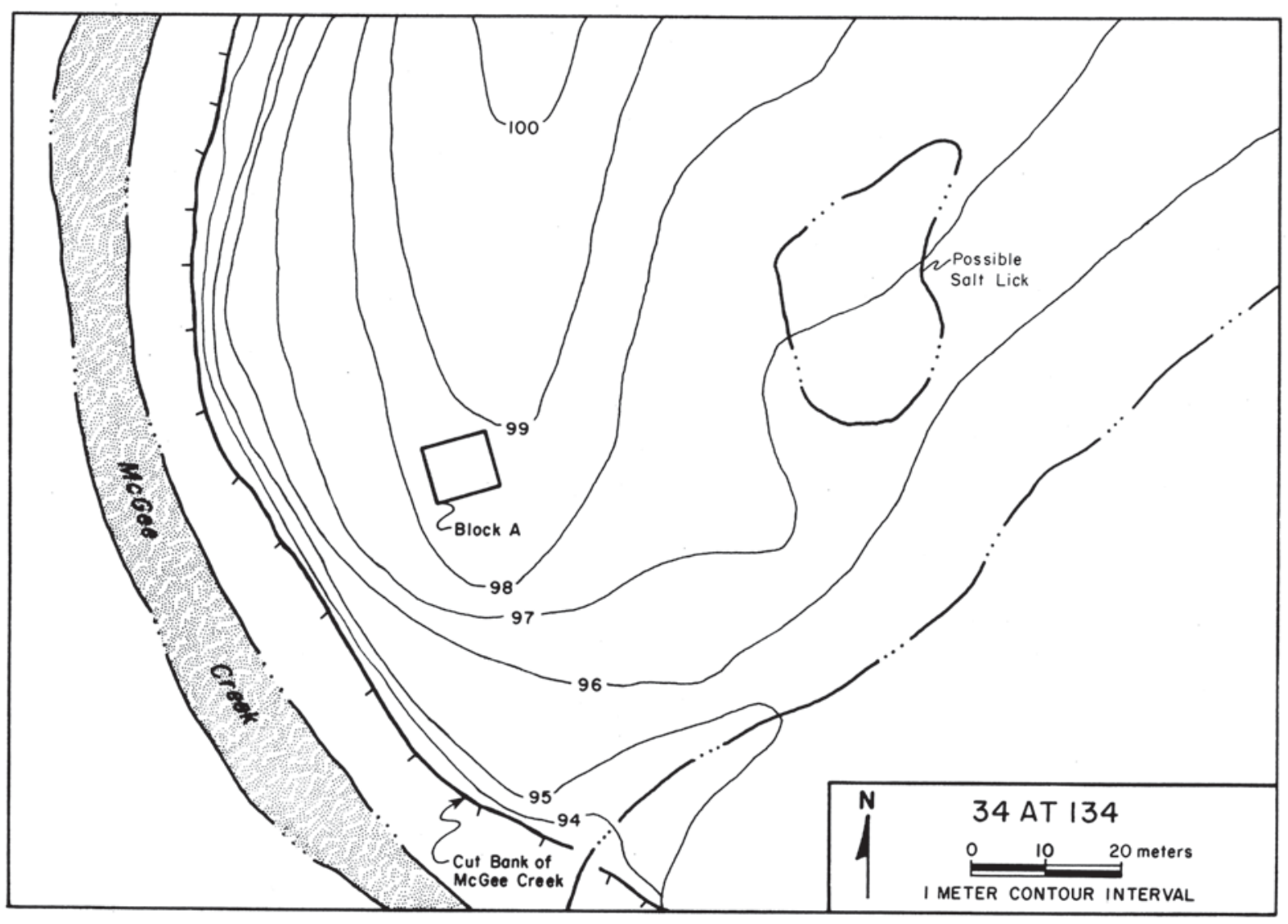

Figure 5. Contour map of the southern end of the Quince site. 


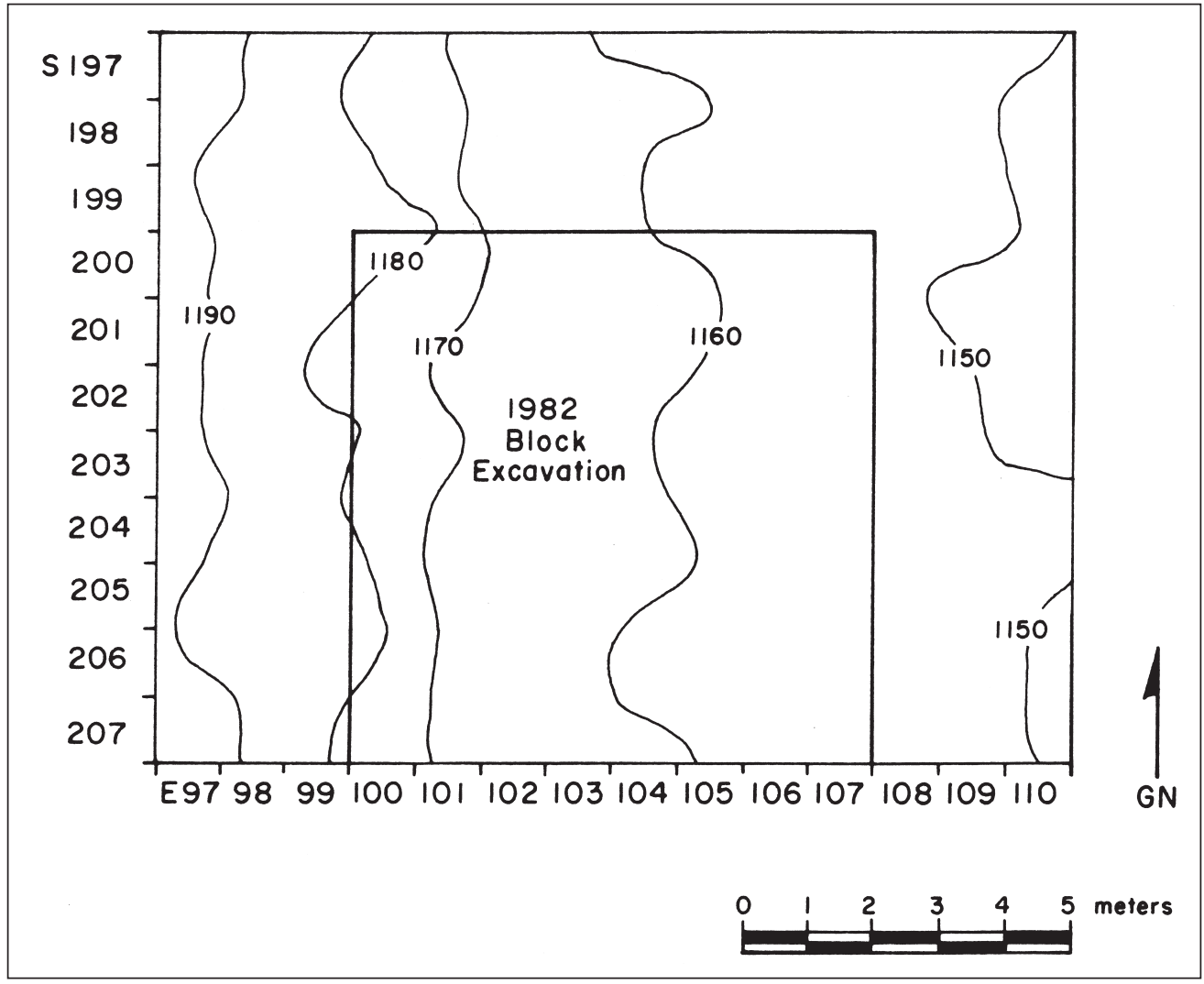

Figure 6. Ground surface elevations below datum in the block excavations at the Quince site.

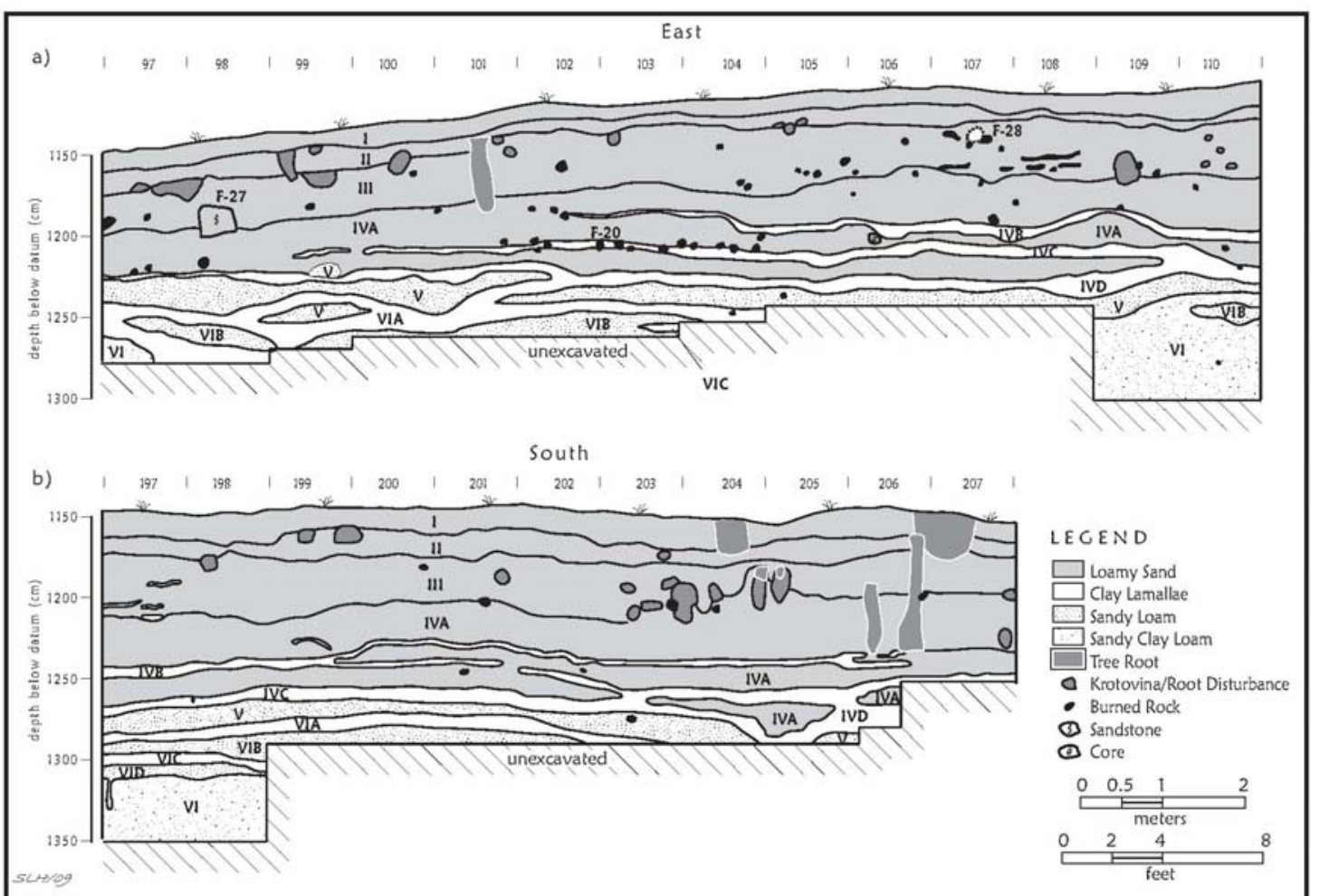

Figure 7. Block Profiles at the Quince site. The Paleoindian Deposits are Zones V-VI: a, profile of the north wall of the block; b, profile of the east wall of the block. 
where the tools, debris, and features appear to be the result of using a particular location for a specific and relatively short period and either single or multiple times. The occupation horizons at the Quince site are not separated from each other by sterile alluvial deposits, stacked one on top of another like a layer-cake, and are best considered "coarse-grained" in character. That is to say, they are probably the product of several occupational episodes within a single depositional unit, and these occupational episodes are not recognizable in either vertical or horizontal contexts.

Defined Paleoindian occupation horizons include:

Occupation Horizon 9B, 122-126 cm bs

Occupation Horizon 10, 131-138 cm bs

Occupation Horizon 11, 142-146 cm bs

Occupation Horizon 12, 150-154 cm bs

Occupation Horizon 13, 162-165 cm bs

Occupation Horizon 14, $177 \mathrm{~cm}$ bs

Artifacts continued to be recovered in very low densities to about $3 \mathrm{~m}$ bs in the excavations, but because of the limited spatial scale of the excavations at these great depths, and the few fire-cracked rocks, features, or tools (including no recognizable projectile points) found at these depths, no definite occupation horizons were recognized below $177 \mathrm{~cm}$ bs (Occupation Horizon 15, see below, simply represents the archaeological materials recovered between 180-210 cm bs in the excavations). Occupation Horizon 9A, 111-116 cm bs, probably also belongs to the Paleoindian occupation at Quince, based on the range of chipped stone tools found at those depths, but it has been apparently truncated or eroded prior to the deposition of the overlying Middle Archaic Occupation Horizon 8 cultural materials, and consequently Middle Archaic and Late Paleoindian chipped stone diagnostics are both found in this horizon.

\section{FEATURES}

Four burned rock features were defined in the Paleoindian occupation, two in Occupation Horizon 9B, and one each in Occupation Horizons 11 and 12 (Perttula 1994:79-87). Burned rocks were also present in each of the occupation horizons (including Occupation Horizon 9A), and scattered below them to depths of $215 \mathrm{~cm}$ bs.

The burned rock from the Paleoindian deposits, while not abundant, does document the fact that hot rock cooking (cf. Perttula 2014; Thoms 2008) likely took place during the accumulation of each occupation horizon. These heated stones were used for cooking a variety of food stuffs, likely including roots and other plants, large and small game, and fish (Thoms 2008:452), in pits and earth ovens.

A total of $99 \mathrm{~kg}$ of burned rocks was found in Occupation Horizon 9B, over 84 percent from the two burned rock features (Features 11 and 13) and from excavations within 2-3 $\mathrm{m}$ of the features. Feature 11 was a tightly clustered basin about $1 \times 1 \mathrm{~m}$ in length and width, and $17 \mathrm{~cm}$ in depth from its point of exposure. It contained $78 \mathrm{~kg}$ of burned sandstone rocks of various sizes; densities of $1-2 \mathrm{~kg} / \mathrm{m}^{2}$ were recorded in $41 \mathrm{x} 1$ $\mathrm{m}$ excavation units to the south and southeast. Feature 13 , only partially exposed, was a $9 \mathrm{~cm}$ thick burned rock concentration (weighing $6.5 \mathrm{~kg}$ ) that lay on the surface of Occupation Horizon 9B. It was about 1.2 $m$ in length.

Only small amounts of burned rocks $(4.75 \mathrm{~kg}$ ) were noted in Occupation Horizon 10, and these were in the northwest quadrant of the block excavations (Perttula 1994:Figure 4.29). In Occupation Horizon 11, $10.5 \mathrm{~kg}$ of burned rock was recovered, including $6 \mathrm{~kg}$ from Feature 41 , a 0.7 x $0.5 \mathrm{~m}$ concentration of nine cobble-sized fractured sandstone pieces lying flat on the surface. A second cluster of burned rocks was present about $3 \mathrm{~m}$ to the southwest, and burned rocks were also scattered between the two. 
There were two more diffuse burned rock concentrations in Occupation Horizon 12, one covering about $6 \mathrm{~m}^{2}$, and the second (about two meters to the south) at least $3 \times 5 \mathrm{~m}$ in size; $22 \mathrm{~kg}$ of burned rock were associated with this concentration. At the center of the latter burned rock concentration was a single basin hearth (Feature 12), defined by three relatively large unburned sandstone cobbles at different corners of the basin (Perttula 1994:Figure 4.31b). The burned rock outside the $8 \mathrm{~cm}$ deep basin represents a burned rock pile raked out of the hearth.

Only $1.5 \mathrm{~kg}$ of burned rock were recorded in Occupation Horizon 13, and there were no features exposed in the $12 \mathrm{~m}^{2}$ excavated into these deposits. A small concentration of burned rock $(6 \mathrm{~kg})$ was also defined in Occupation Horizon 14, about 12-15 cm below Occupation Horizon 13, and flat-lying burned sandstone fragments were mapped at $207 \mathrm{~cm}$ bs and $215 \mathrm{~cm}$ bs in Occupation Horizon 15. This was the lowest level in the block excavations where burned rocks were found.

\section{LATE PALEOINDIAN TOOL ASSEMBLAGES}

Not including cores, hammerstones, and ground stone tools, 143 stone tools are included in the Late Paleoindian occupation horizons (Horizons 9A-15) at the Quince site (Table 1). The most common tools in the assemblage as a whole are various unifacial tools and scrapers (37 percent), unfinished bifaces (22.4 percent $)$, and projectile points (21.7 percent), along with biface fragments (14 percent). In general these tools are prevalent in each of the larger tool assemblages from Occupation Horizons 9B, 10, and 11 (see Table 1).

Table 1. Lithic Tools, Cores, and Ground stone tools from Component V at the Quince site.

\begin{tabular}{|c|c|c|c|c|c|c|c|c|c|}
\hline \multirow[b]{2}{*}{ Tool Classes } & \multicolumn{8}{|c|}{ Occupation Horizons } & \multirow[b]{2}{*}{$\mathrm{N}$} \\
\hline & $9 \mathrm{~A}$ & $9 \mathrm{~B}$ & 10 & 11 & 12 & 13 & 14 & $15^{*}$ & \\
\hline Projectile point & 4 & 7 & 7 & 5 & 1 & 2 & 1 & - & 27 \\
\hline Drill (final-stage)** & - & - & 3 & - & 1 & - & - & - & 4 \\
\hline Quince scraper & 2 & - & 2 & - & - & - & - & - & 4 \\
\hline Bifacial scraper & - & 1 & - & - & - & - & - & - & 1 \\
\hline Biface fragment & 2 & 7 & 4 & - & 6 & 1 & - & - & 20 \\
\hline Adze & - & - & - & - & - & 1 & - & - & 1 \\
\hline Unfinished biface & 3 & 9 & 11 & 8 & - & 1 & - & 1 & 33 \\
\hline Unifacial tool & 3 & 14 & 21 & 8 & 4 & 2 & - & 1 & 53 \\
\hline Subtotal & 14 & 38 & 48 & 21 & 12 & 7 & 1 & 2 & 143 \\
\hline Metate & - & 1 & 1 & - & - & - & - & - & 2 \\
\hline Core & 5 & 11 & 8 & 1 & 2 & 1 & - & 1 & 29 \\
\hline Hammerstone & 1 & 1 & - & - & - & - & - & - & 2 \\
\hline Subtotal & 6 & 13 & 9 & 1 & 1 & 1 & - & 1 & 33 \\
\hline Totals & 20 & 51 & 57 & 22 & 14 & 8 & 1 & 3 & 176 \\
\hline
\end{tabular}

* All materials found below ca. $177 \mathrm{~cm}$ bs have been lumped into a putative Occupation Horizon 15; ** Final stage lanceolate (cf. Goodyear 1974; Galm and Hofman 1984)

Cores are present in $\mathrm{OH} 9 \mathrm{~A}-\mathrm{OH} 13$ and $\mathrm{OH}$ 15, and are particularly abundant in $\mathrm{OH} 9 \mathrm{~A}$ (25 percent of the lithic assemblage), $\mathrm{OH}$ 9B (21.5 percent), and $\mathrm{OH} 10$ (14 percent) of the Component $\mathrm{V}$ occupation horizons; $\mathrm{OH} 9 \mathrm{~A}$ and $\mathrm{OH} 9 \mathrm{~B}$ also have hammerstones. The few ground stone tools are from $\mathrm{OH} 9 \mathrm{~B}$ and OH 10 (see Table 1). 


\section{Occupation Horizon 9A}

Fourteen tools, five cores, and one hammerstone were found in the uppermost Late Paleoindian component, The Ouachita Mountains have "diverse knappable materials" (Wyckoff 2005b:93-94). In Occupation Horizon 9A, 90 percent of the tools and cores are made of local Ouachita Mountains cherts, one possible novaculite core (from the Black Knob Ridge outcrop?), and a sandstone hammerstone (see Table 1). Among the bifaces, the two thicker unfinished pieces were broken by end shock during manufacture, and the third was broken by a lateral fracture. This biface was apparently utilized before it was broken because one lateral margin has a $25 \mathrm{~mm}$ long area with overlapping micro-step fractures and a steep edge angle from use wear. The two biface fragments are indeterminate portions of finished bifacial tools, probably projectile points or thinned bifaces ready for hafting; one specimen is a distal tip with serrated edges, suggesting it was from an implement that had been resharpened before it was broken (Figure 8a).

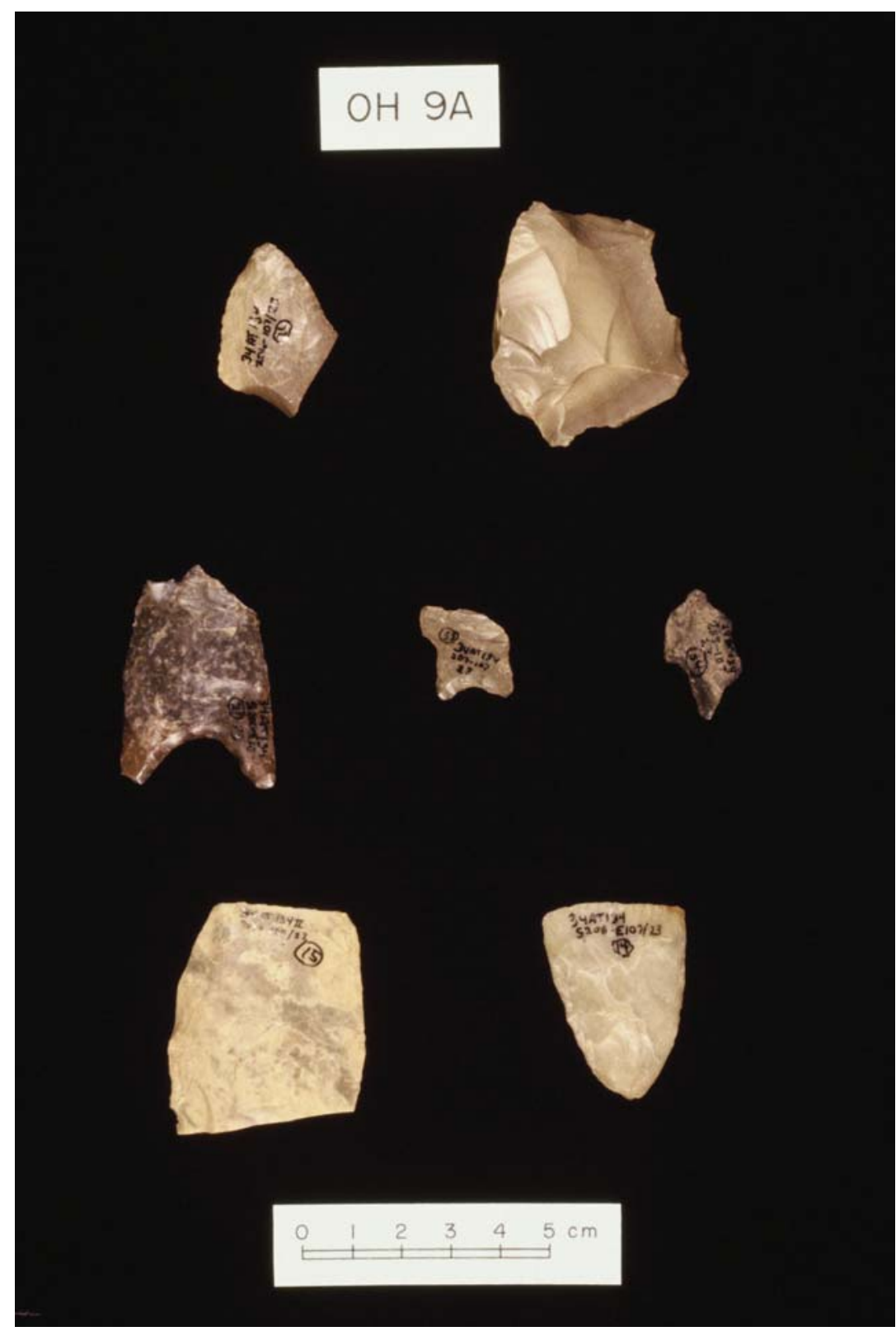

Figure 8. Tools and core from Occupation Horizon 9A: a, bifacial tool fragment; b, core; c, Dalton point, lanceolate variety; d-e, Uvalde points; f-g, Quince scrapers. 
None of the projectile points are complete, and one is a base/hafting element of a straight-stemmed form that has been basally and laterally ground. Two others resemble Middle Archaic Uvalde points that have resharpened blades and lateral and basal grinding (see Figure 8d-e); these points are believed to have originated from the overlying Middle Archaic deposits in Occupation Horizon 8.

The fourth projectile point is a lanceolate form with extreme basal depth and prominent ears, blade resharpening, and serration (see Figure 8c), and is probably a lanceolate variety of the Dalton point (cf. Johnson 1989). The width, stem width, and basal depth of this particular Quince site point differs considerably from Dalton examples in other occupation horizons at the site, as well as Dalton points at the Billy Ross (Galm and Hofman 1984:Table 4), Bell (Wyckoff 1968:45 and Plate V:1), and Packard (Wyckoff 1985:Figure 4a-b and d-e) sites in eastern Oklahoma. It is manufactured on a heat-treated purple-brown chert thought to have originated in the Edwards Plateau in Central Texas (cf. Frederick and Ringstaff 1994), but the identification has not been confirmed through ultraviolet stimulated fluorescence (e.g., Hofman et al. 1991). The blade was broken by a large impact fracture that extended to the hafted margin, and then it was subsequently resharpened before being discarded.

Unifacial tools include two unilateral obverse flake tools and a end-side scraper. The working edges of the scraper have edge angles between 50-55 degrees, and there is also a retouched notch on the obverse surface at the proximal end of the tool.

Two of the distinctive Quince scrapers are among the Occupation Horizon 9A tool assemblage (see Figure 8f-g). These are bifacially worked and ovate-shaped, with a steep (65-70 degrees) bifacial and beveled bit. LeRoy Johnson, who first labeled these small biface scrapers as "Quince scrapers," further described them as follows:

most Quince scrapers...are bifacial to some degree. But occasionally the underside, representing the original ventral surface of the flake, has large areas that are either not retouched or which are not well penetrated by invasive retouch. Other specimens are quite bifacial, as the bit almost always is. Yet the bit is beveled, and most chipping was done from one face (Story 1990:197).

The first Quince scraper has been manufactured on a high quality heat-treated chert, and has a 28.5 $\mathrm{mm}$ long bit edge; the bit is $6 \mathrm{~mm}$ in height (see Figure $8 \mathrm{~g}$ ). Small parallel flakes were also removed on the opposite surface, but the edge has not been steepened by further retouching. The second scraper, although broken, has a working bit edge of $28 \mathrm{~mm}$ in length and $7 \mathrm{~mm}$ in height; the bit edge has a series of parallel flakes with step fracture terminations caused from tool use (see Figure 8f).

The Quince scraper appears to be "part of a Dalton assemblage found mostly in Cross Timbers-Tall Grass Prairies, from the North Canadian south to the Red River drainage" (Story 1990:197). Near to the Quince site, they have been found in assemblages with Late Paleoindian materials at sites on the Kiamichi River (Rohrbaugh et al. 1971:Plate XX:9-11; Perino and Bennett 1978:Figure 10d-e) in southeastern Oklahoma, in the Muddy Boggy Creek drainage south of the Ouachita Mountains (Baugh and Hofman 1979:Plates 98f and 118h), and in several sites in the Red River drainage basin in Northeast Texas (Lorrain and Hoffrichter 1968:Figure 9; Mallouf 1976:Figure 137n-o). Ballenger (2001:Figure 18g-k, m-q) has also documented Quince scrapers from the Dirty Creek and McKellips localities in the Arkoma basin in eastern Oklahoma.

The five cores from Occupation Horizon 9A include two single platform, one multiple platform, one radial, and one discoidal form. The single platform cores are on materials that may have been derived from the Arkansas Novaculite formation (see Banks 1984:90-91), while the other three are on cherts resembling Big Fork chert and Stringtown flint. These raw materials were probably collected from redeposited Johns Valley shale sources abundant throughout the McGee Creek drainage basin. 


\section{Occupation Horizon 9B}

There are 51 tools and cores in this occupation horizon, dominated by bifacial tools and tool fragments, unifacial tools, and cores (see Table 1). In addition to the chipped stone tools, a quartzite hammerstone and a sandstone metate were also recovered from these Late Paleoindian archaeological deposits.

The majority of the nine unfinished bifaces are thick, have irregular cross-sections, and undulating margins indicative of initial efforts to shape and thin different kinds of raw materials for the production of bifacial tools. None of the unfinished bifaces have evidence of use-wear, consistent with these pieces representing the by-products of biface manufacture. Novaculite, quartzite, siliceous shale, Big Fork chert, and Stringtown chert were utilized in the production of bifacial tools. Lateral fractures on the broken bifaces probably were the result of end shock during attempts at thinning, snapping the tool at its end. One of the thin unfinished bifaces has a pot-lid fracture, and this occurred subsequent to the end shock fracture that caused the tool to be discarded. Another thin biface has a regularized oval shape and abraded/smoothed lateral and basal margins. It is probably a preform for a final or completed lanceolate projectile point.

Among the biface fragments are three distal tips, three proximal fragments, and a medial section; they appear to be fragments of finished tools. One distal tip has been smoothed on the remaining lateral margin, and the shape of the blade suggests the tool has also been resharpened (Figure 9e), but the resharpening did not alter the blade symmetry as alternate beveling does on the Dalton points in the Quince assemblage. One other basal bifacial fragment, broken by a lateral fracture, has been basally thinned and smoothed like the completed projectile points found in Occupation Horizon 9B, but it is $43 \mathrm{~mm}$ wide at the base (Figure $9 \mathrm{~d}$ ), indicating that it is not a projectile point fragment. The medial section is from a parallel-flaked biface, almost certainly a Paleoindian lanceolate point. It was broken by an impact fracture, and related end shock, that removed the distal end of the tool (Figure 9f).

The projectile points in Occupation Horizon 9B include an advanced stage Dalton, a parallel-collateralflaked lanceolate (not resharpened) point fragment (see Figure 9h), an alternately beveled stemmed form with a concave base, and two other lanceolates that appear to be Dalton points. The other two projectile points are stemmed forms that may not be associated with the other Late Paleoindian tools.

The advanced stage Dalton point has been resharpened (but not beveled) by unifacial flaking after the tip received an impact fracture. The point has markedly concave basal and lateral margins that terminate in pronounced ears (see Figure 9k). The basal depth and stem width on this point are comparable to the large sample of Dalton advanced stage (Category 1b) points from the Billy Ross site in Haskell County, Oklahoma (Galm and Hofman 1984:Table 4).

The beveled stemmed form has right and left blade beveling, unifacial blade serration, and an overall asymmetrical appearance (see Figure 91). The base is concave, with lateral and basal grinding; the basal grinding is more pronounced. The point has been manufactured on a fine-grained olive black quartzite, a raw material that appears to be somewhat common in the Broken Bow area of southeast Oklahoma (Don G. Wyckoff, 1983 personal communication).

The two Dalton lanceolate point bases are from projectile points snapped by lateral fractures. The first (tan chert) has a concave base with pronounced lateral and basal grinding, and the lateral margins are slightly concave, ending in definite "ears," with the blade edges bifacially retouched (see Figure 9i). The base has been thinned on one side by the removal of a series of 3-4 vertically oriented and parallel flakes; thinning was accomplished on the other side by the removal of overlapping vertical and collateral flakes. The second base (quartzite) is also markedly concave, with heavy grinding and polish visible on the lateral and basal margins of the remaining portions of the tool. Blade edges are straight to slightly convex near the mid-portion of the point, and the blade was thinned by a combination of overlapping collateral and vertical flaking, leaving an unthinned medial ridge. It has pronounced ears (see Figure 9j). 


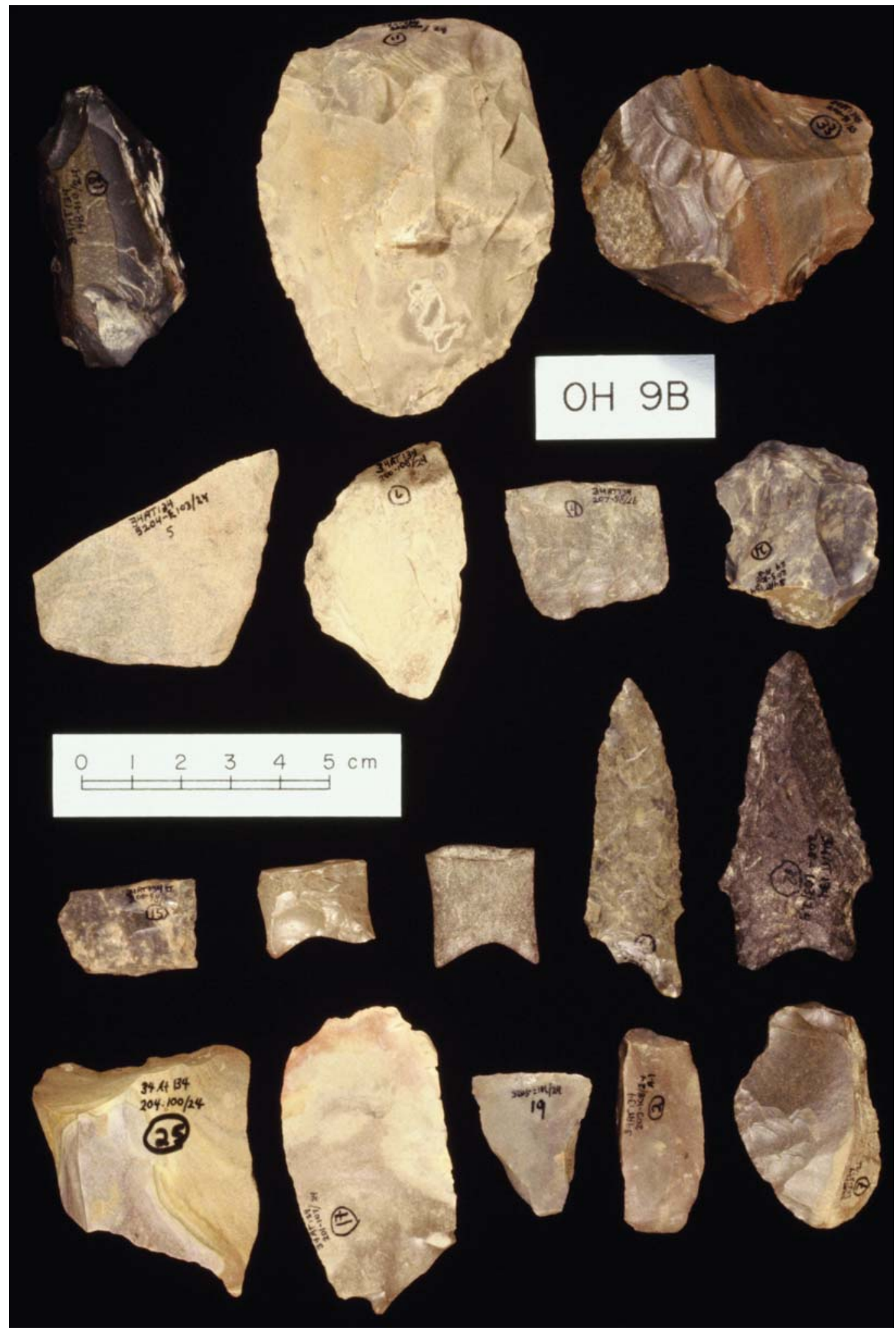

Figure 9. Chipped stone tools and cores from Occupation Horizon 9B: a, bifacial scraper; b, large radial core; c, multiple platform core; d-f, biface fragments; g, multiple platform core; $\mathrm{h}$, lanceolate point fragment; i, lanceolate Dalton point; $\mathrm{j}$, quartzite lanceolate Dalton point; $\mathrm{k}$, advanced stage Dalton point; 1 , beveled stemmed point; $\mathrm{m}-\mathrm{p}$, unifacial retouched flake tools; q, side scraper. 
The 15 flake tools comprise end scrapers $(n=3)$, side scrapers ( $n=5$, see Figure 9q), end/side scrapers $(n=1)$, retouched/utilized pieces $(n=5)$, and a bifacial scraper. The high frequency of scrapers is a distinctive characteristic of the Late Paleoindian lithic assemblages at the Quince site. Edge angles between 60-70 degrees are characteristic of the Occupation Horizon 9B scraper tools. The retouched/utilized pieces have unilateral obverse and unilateral distal alternate retouch/use (see Figure 9m-p). The bifacial scraper was manufactured on a cortical flake of Big Fork chert (see Figure 9a), and the working edge is marked by a $30 \mathrm{~mm}$ long retouched edge with micro-step fractures within larger flakes used to shape the piece. The edge angle of the tool ranges between 30-40 degrees. Raw materials used were predominately cherts gathered from the Johns Valley shale, along with quartzite, Big Fork chert, Stringtown chert, and a large cortical flake of banded chert from the Arkansas novaculite formation exposed at Black Knob Ridge. One flake tool has a distinctive weathered cortex that might be from the Wapanucka limestone Chickachoc chert unit (Banks 1984:90).

Among the 11 cores were single platform (27 percent), multiple platform (9 percent) (see Figure 9c, g), radial (36 percent), and discoidal (9 percent) examples, as well as two core fragments. Quartzites, Big Fork chert, and siliceous shale raw materials were used as sources of flakes and tools, several of which were from large cobbles more than $70 \mathrm{~mm}$ in length, width, and thickness. Two of these larger cores were of a coarse quartzite, and only a limited number of flakes were removed from single platforms. The third large core is a radial core of unidentified chert, recovered in situ adjacent to Feature 11 (see Figure 9b). The other cores, between 30-50 mm in length and width and mostly of chert, have evidence of numerous flake removals to the point where the successful removal of large flakes, or the continued thinning of the piece, would have been difficult.

The hammerstone has battering, crushing, and abrasive wear on either end of a $73 \times 45 \mathrm{~mm}$ cobble. The metate was manufactured on an unshaped tabular piece of locally available Atoka Formation sandstone.

\section{Occupation Horizon 10}

Occupation Horizon 10 has the largest sample of chipped stone tools from the Late Paleoindian archaeological deposits at the Quince site. This includes 25 bifacial tools, 21 unifacial tools, and two Quince scrapers. There is also a single metate and eight cores in this assemblage.

A lanceolate variety of Dalton point in this occupation horizon was made from a local coarse-grained quartzite (Figure 10c). It has been heavily ground along the basal and lateral margins. The blade has been alternately beveled and unifacially serrated; polish visible on the tip suggests it was employed to pierce or drill hard materials, as well as serving as a projectile point.

Two of the points from this occupation horizon are side-notched Graham Cave forms made of chert and a dark gray quartzite (see Figure 10a-b). One of these points, bifacially resharpened, but not alternately beveled (see Figure 10b), is similar to a specimen recovered at the Packard site in the Late Paleoindian Packard complex deposits (Wyckoff 1984:Figure 6.2q, 1985).

Among the projectile points in $\mathrm{OH} 10$ are also two large broad-bladed forms lacking fully shaped basal/lateral margins, but with evidence of blade resharpening (Figure $11 \mathrm{j}-\mathrm{k}$ ). Both of these may be Dalton preforms (see Wyckoff 1999:Figure 6b). There are also two ears from ground lanceolates; and three final stage stemmed points on Woodford and Big Fork cherts with drill-like and alternately beveled blades (see Figure 10d-f). The haft element on these final stage points is heavily ground on the basal and lateral margins.

Eight of the bifacial tools, made from local Woodford and Big Fork cherts, are thick preforms with irregular cross-sections and crudely percussion-shaped lateral edges (see Figure 11b, f, h). These have been broken by lateral or transverse fractures caused by end shock; in one case, the end shock sheared off a longitudinal section of the preform. These preforms represent broken and unsuccessful attempts to thin and 


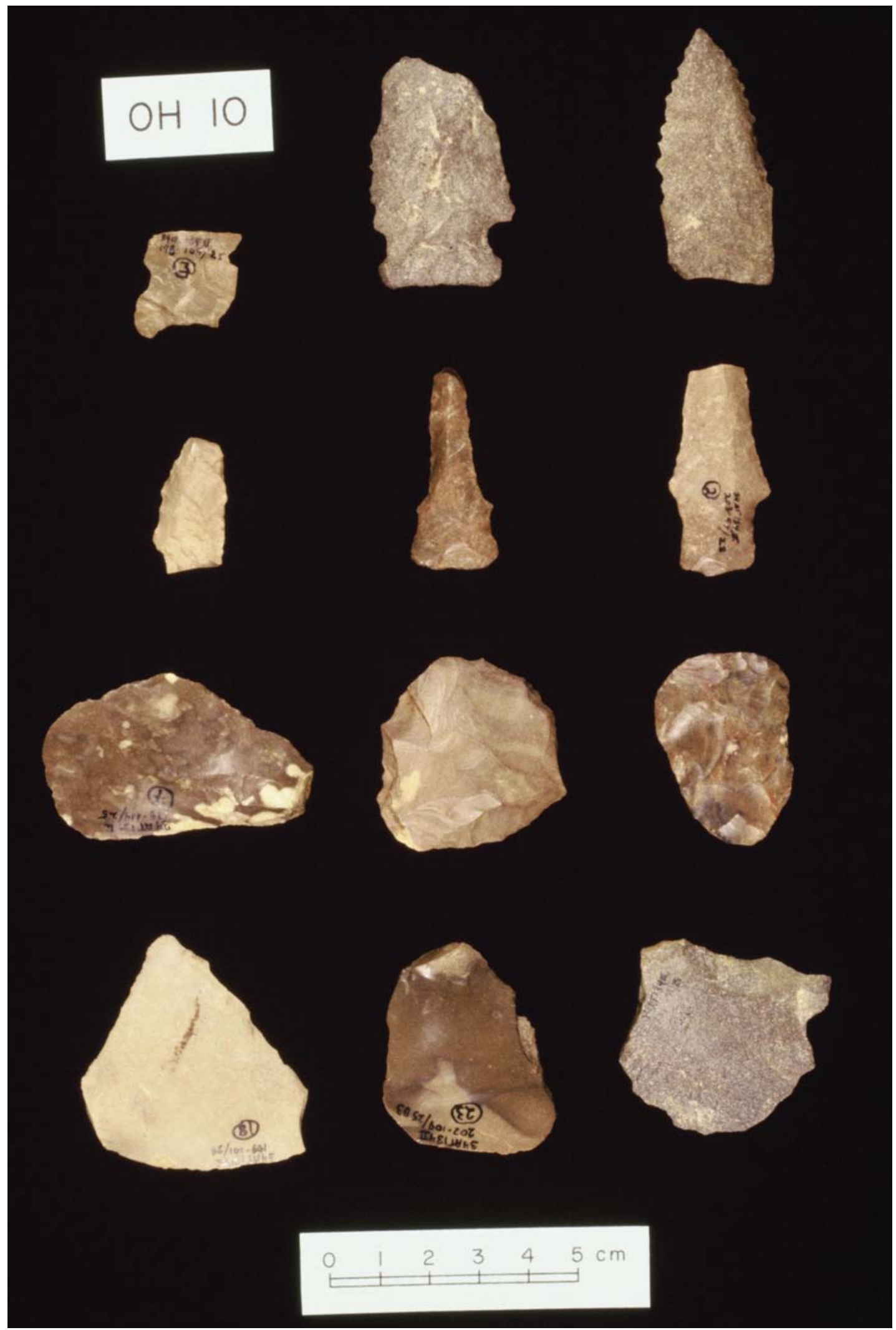

Figure 10. Projectile points and scrapers from Occupation Horizon 10 at the Quince site: a-b, Graham Cave side-notched points; c, Dalton point, lanceolate variety; d-f, stemmed points with drill-like and alternately beveled blades; $\mathrm{g}-\mathrm{h}$, $\mathrm{j}$, end-side scrapers; $\mathrm{i}, \mathrm{l}$, end scraper; $\mathrm{k}$, side scraper. 


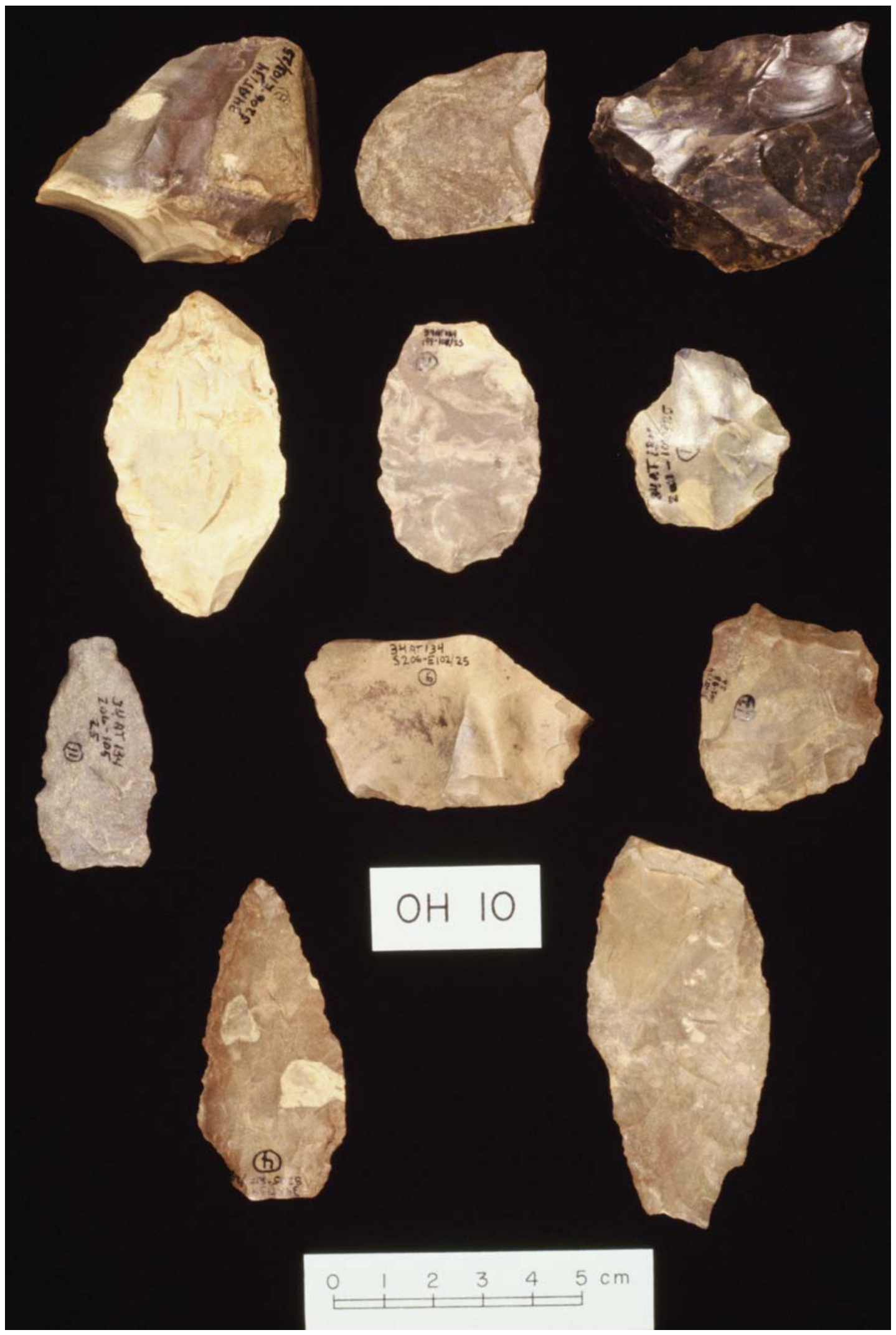

Figure 11. Chipped stone tools and cores from Occupation Horizon 10 at the Quince site: a, c, cores; $b, f, h$, thick biface d-e, g, thin bifaces; i, bifacial tool fragment; j-k, Dalton point preform. 
shape cobble-sized pieces of raw material into thin, ovate bifaces that would have eventually been hafted or modified as lanceolate projectile points.

There are three thin bifaces made from quartzite, a local chert, and novaculite (see Figure 11d-e, g). The complete thin bifaces average $57 \mathrm{~mm}$ in length, $30 \mathrm{~mm}$ in width, and $9.3 \mathrm{~mm}$ in thickness. They are approximately the same length and width as the completed projectile points, while the completed projectile points average only $6.9 \mathrm{~mm}$ in thickness. After the bifaces had been shaped and the lateral margins trimmed, they would have been thinned, then ground and/or notched for use as projectile points. The complete thin bifaces in the $\mathrm{OH} 10$ assemblage were presumably discarded because the particular pieces were not amenable to projectile point manufacture; none of the thin bifaces have any evidence of microscopic edge damage or use wear.

The bifacial fragments in $\mathrm{OH} 10$ include two basal sections from what appear to be projectile points, except they lack basal grinding, and two medial fragments. The first of these is made of Big Fork chert, and was broken after exposure to fire as one surface of the tool has a pot-lid fracture. The other medial fragment is represented by three pieces from a thin biface, two of which can be conjoined. This biface had been resharpened (see Figure 11i), then exposed to fire, where a small pot-lid fracture removed part of the tool's use worn edge (it has a 50 degree edge angle, and probably was utilized as a scraping implement).

The first of the Quince scrapers in $\mathrm{OH} 10$ is made from a mottled brown, gray, and black chert (see Figure 11e). The bifacial working edge appears to have been resharpened shortly before it was discarded because only remnants of the original bifacial edge are preserved adjacent to the more recent resharpening flakes. As a result, the working edge (55 degrees) is not as steep as that noted on the Quince scrapers from $\mathrm{OH} 9 \mathrm{~A}$ and $\mathrm{OH}$ 9B. The second Quince scraper, possible made from Frisco chert or Antlers formation chert (cf. Wyckoff 2005b), is a fragmentary piece that has a portion of the bit or working edge (65-67 degrees) (see Figure 11i), and may represent a deliberate removal from a resharpening edge.

The unifacial flake tools are comprised of nine scrapers and 12 retouched pieces with various retoucheduse worn areas. The scrapers, among them four end scrapers (mean edge angle of 57 degrees) (see Figure 10i, 1), two side scrapers (mean edge angle of 70 degrees) (see Figure 10k), and three end-side scrapers (mean edge angle of 63 degrees) (see Figure 10g-h, j), are manufactured on a range of chert and quartzite flakes, of which only a regularized shape and flake size was apparent for the end-side scraping tools. This suggests a deliberate selection of particular flakes considered suitable for the manufacture of end-side scrapers, as well as a specific formalized shape for these tools. The working edge of the end-side scrapers extends along all available lateral edges. End and side scrapers have shorter retouched working edges on irregular types of flake shapes. One of the end scrapers is a unifacial bit from a resharpened tool. The edge margin was removed to rejuvenate the edge of the tool.

The unifacial retouched or expedient tools in $\mathrm{OH} 10$ are on Big Fork chert, Woodford chert, chalcedony, jasper, siliceous shale, and quartzite, all considered to be locally available raw materials. Several of the chert tools, however, are a gray to banded brown-gray color, and this material may be locally available in the Muddy Boggy Creek and McGee Creek drainage basins. These tools have unilateral (50 percent), unilateral and distal (25 percent), distal (17 percent), and bilateral and distal ( 8 percent) working edges.

The cores include single platform, multiple platform, pyramidal, and tested cobble classes made from local cherts and quartzite (see Figure 11a, c); one multiple platform core is made on petrified wood. The exhausted pyramidal core is on a lustrous, olive-gray chert; no tools in the Late Paleoindian deposits at the site were made of this distinctive brecciated material, although there are two projectile points of this material from the overlying Middle Archaic $\mathrm{OH} 8$.

A small section of a sandstone metate came from $\mathrm{OH} 10$. One surface of the tool was shaped by grinding, with striations visible on the flat grinding surface. 


\section{Occupation Horizon 11}

The 21 chipped stone tools in $\mathrm{OH} 11$ include 13 bifacial tools and eight unifacial tools, and there is one multiple platform core of Big Fork chert. This occupation horizon has the highest relative proportion of bifacial tools of any of the Late Paleoindian occupation horizons with reasonable sample sizes (i.e., OH 9B-13).

Among the bifacial tools are five thin $(<10 \mathrm{~mm})$ preforms, mostly fractured laterally during manufacture, with a regularized ovate shape and marginal retouch, but lack haft treatment other than edge abrasion to facilitate basal thinning; none have dorsal cortex (Figure 12d-e). The thin preforms were manufactured on quartzite $(\mathrm{n}=2)$ and local cherts $(\mathrm{n}=3)$ from unknown sources.

There are three thick $(>10 \mathrm{~mm})$ preforms in $\mathrm{OH} 11$. These are ovate-shaped, have cortical remnants, as well as irregular lateral margins characterized by large flake removals (see Figure 12a-c). They were not completely thinned because of either an internal flaw in the raw material or an unwieldy knot that could not be removed during knapping. All three were on local chert, including one that had a weathered chalky cortex (see Figure 12a), suggesting the raw material may have been collected near a Wapanucka limestone source area or gravel bed in the Muddy Boggy Creek drainage.

Four of the five projectile points in this occupation horizon are relatively complete, and the other is an ear from a lanceolate form. The first of the nearly complete points is an initial stage Dalton (Galm and Hofman 1984:Figure 5a) made from a heat-treated chert of presumed non-local origin. A rudimentary shoulder above the lateral grinding of the half element is present on one edge of the point, and the other shoulder has been removed by a longitudinal impact fracture (see Figure 12h); the tip was subsequently resharpened. The second is a lanceolate made of Woodford chert; it resembles closely one of the lanceolates recovered in the Late Paleoindian deposits at the Bell site (Wyckoff 1968:45 and Plate V:3, 1984:127-134). The blade has been formed by parallel and collateral flaking, and is laterally ground (see Figure 12f). Damage to the tip and the base suggest that the point was broken by an impact fracture, then subsequently resharpened. The edge modification associated with this resharpening and initial beveling may have resulted in the burin-like flake driven off one lateral margin of the tool.

The other three points from $\mathrm{OH} 11$ include single examples of extensively resharpened and heavily ground straight-stemmed, side-notched, and expanding stem forms; all three points have beveled blades (see Figure 12g, i). Because they are not lanceolates, these forms may be stratigraphically incongruous, and hence likely originated from an upper Component $\mathrm{V}$ archaeological deposit. The blade resharpening on the straight-stemmed form produced a blade with a biconvex cross-section, resembling a drill, and the resharpening is comparable to that of final stage Dalton point resharpening.

The unifacial tools are dominated by scraping implements, including one end scraper, two side scrapers, and two end-side scrapers (see Figure 12k-1). The scrapers have heavily-worn use areas, with edge angles that range from 64 to 71 degrees. There are also three unifacially retouched tools with bilateral retouch and evidence of use wear (see Figure 12j).

\section{Occupation Horizon 12}

There are two lanceolate projectile points in this occupation horizon. One has a ground base and lateral margins, a distinctive shoulder, and a resharpened blade. It is manufactured on a heat-treated blue-gray chalcedony. The base of this lanceolate is slightly concave, with a contracting stem, and it was thinned by the bifacial removal of a series of small ovate flakes (Figure 13f). A remnant of the striking platform on one of the "ears" indicates the lanceolate was made on a flake blank. The blade was reworked subsequent to the fracture caused by an impact blow, chipped bifacially to a rough point, then alternately beveled. Similar lanceolates have been found at the Bell site in the Little River drainage (Wyckoff 1968:46 and Plate 


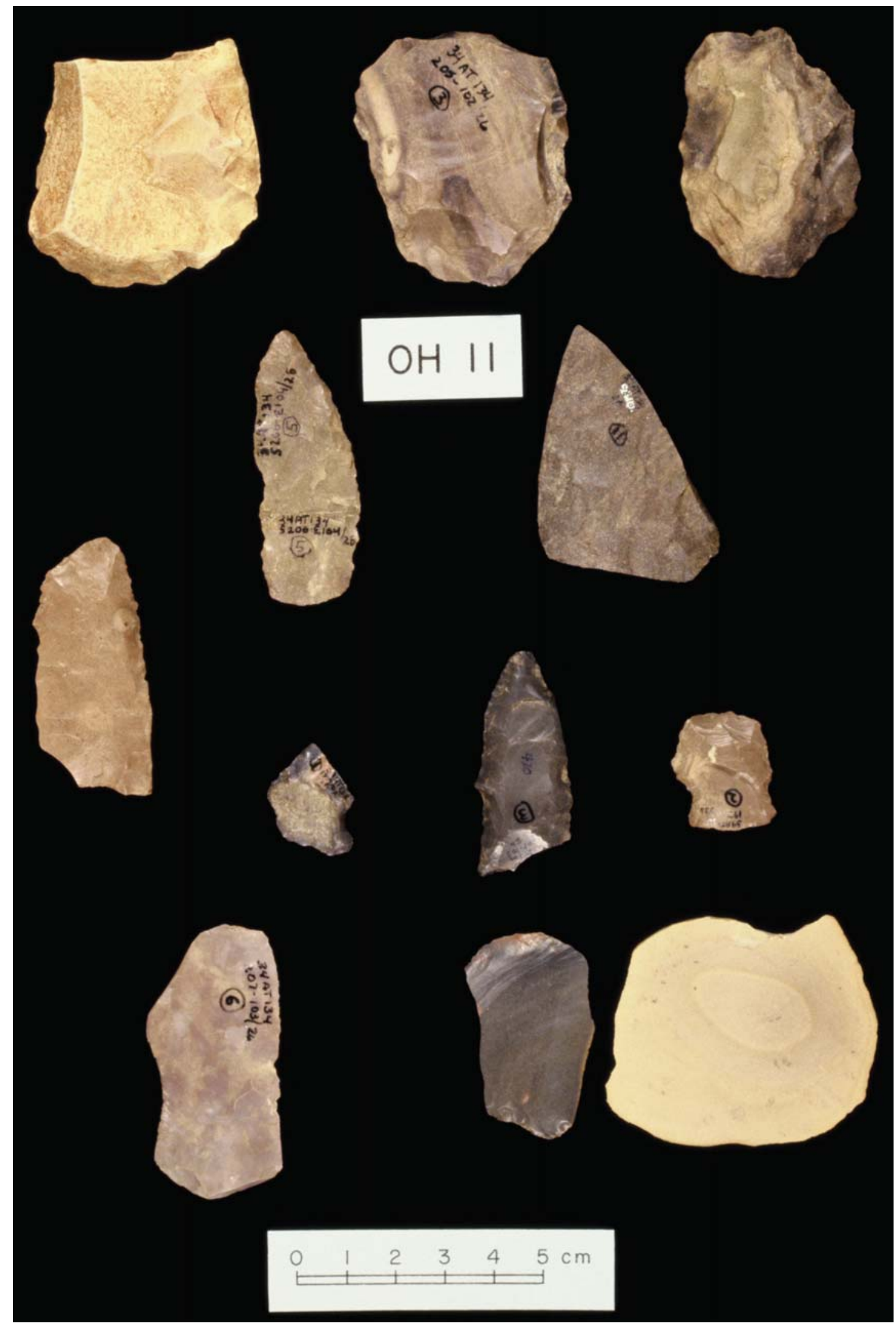

Figure 12. Chipped stone tools from Occupation Horizon 11: a-c, thick bifaces; d-e, thin bifaces; f, lanceolate point; g, side-notched; h, Dalton point; i, resharpened dart point; $j$, unifacial retouched tool; k-l, end-side scrapers. 


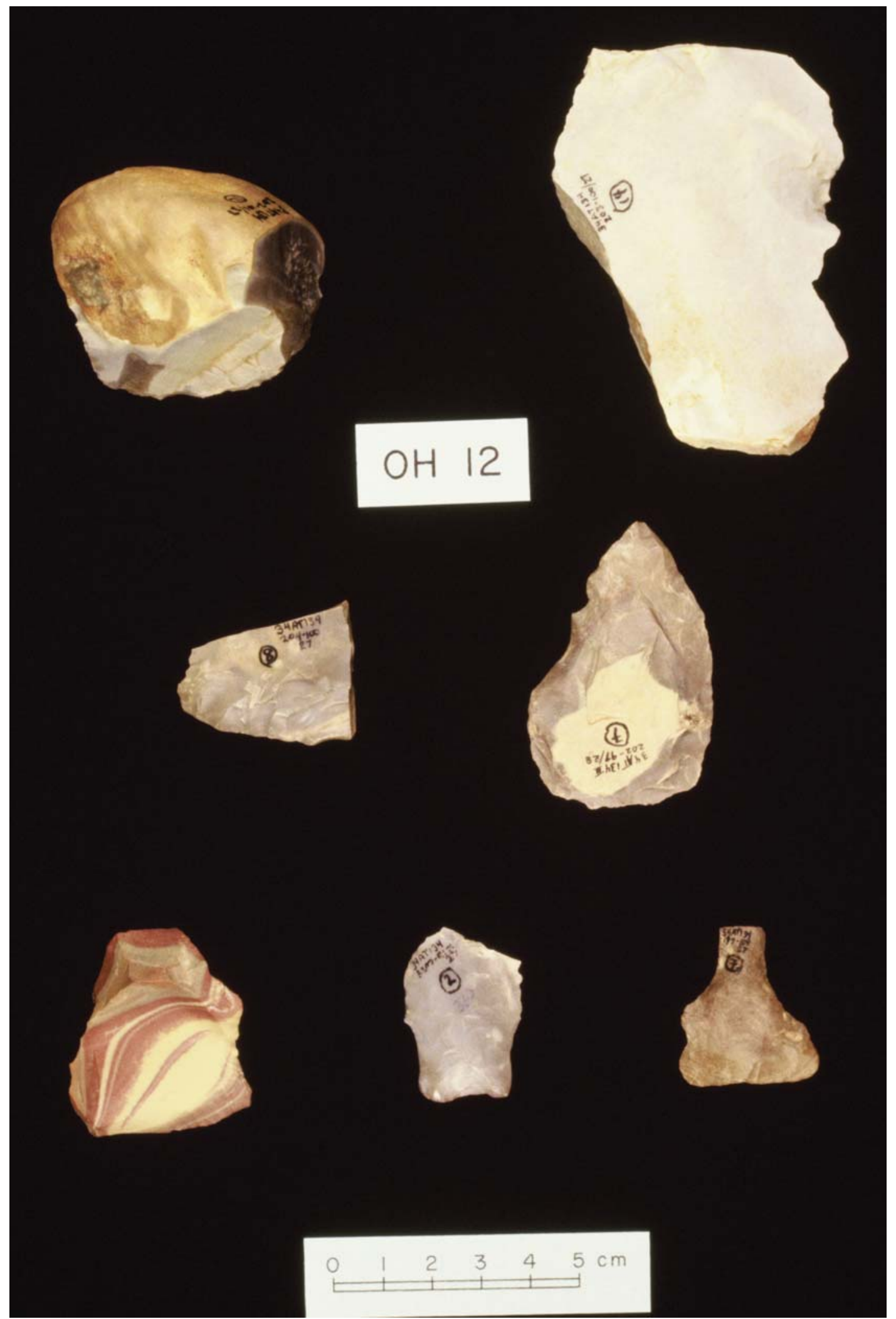

Figure 13. Chipped stone tools and core from Occupation Horizon 12 at the Quince site: a, core; b-d, thin and thick bifaces; e, unifacial tool; lanceolate point; f, final stage Dalton point. 
V:5). The other is a "final stage" (cf. Goodyear 1974; Galm and Hofman 1984; Ballenger 2001:Figure 7) Dalton lanceolate made on Woodford chert (Figure 13g). Lateral and basal margins have been ground, and the base has been thinned by the removal of 3-4 overlapping and parallel flake scars. The blade had been resharpened to the typical biconvex shape of a final stage lanceolate, then it snapped laterally. Before the point was discarded, but after its initial manufacture and grinding of the basal element, the base was further modified by side-notching one margin of the haft; the side notch was not ground. It is possible that both margins of the haft were side-notched, and that the side notch was removed when the projectile point was extensively resharpened.

Four of the six unfinished bifaces in Occupation Horizon 12 are thick ( $>10 \mathrm{~mm}$ in thickness), while the other two are thin $(<10 \mathrm{~mm}$ ) (see Figure 13c). Five of these bifaces (four chert and one novaculite) were broken during manufacture (although the cortex had been removed from both faces of each) (see Figure 13b), but the complete novaculite biface was discarded before final tool shaping (see Figure 13d) for no apparent reason relating to knapping success, and they were each snapped by end shock fractures. The unfinished novaculite bifaces had received limited thinning, cortex removal, and shaping before they were discarded. None had been heat-treated.

Included in the unifacial tools are a side scraper, a flake with distal obverse retouch, and two flake tools with a scraper edge and opposing retouch. The side scraper has an edge angle of 68 degrees, and is manufactured on a brown-gray chert flake; it was broken across the working edge and then discarded. The distal obverse retouched flake has an $8 \mathrm{~mm}$ long working edge. A third flake tool has distal obverse scraper retouch and unilateral inverse retouch on a large cortical flake of banded yellow-red chert (see Figure 13e). The other multiple tool is a Big Fork chert cortical flake with end scraper and bilateral alternate retouched working edges.

There are two cores from Occupation Horizon 12. One is a radial core of black Big Fork chert, while the other is a single platform core of a raw material visually resembling novaculite. This core has a rounded, stream-rolled cortex (see Figure 13a).

\section{Occupation Horizon 13}

There are eight tools in this occupation horizon, including bifaces, unifaces, and a single core. The unfinished bifaces include a medial section of a thick biface (local dark brown-blue chert) broken during manufacture (Figure 14b) and a small section of the edge of a fractured thin biface (heat-treated gray chert). The tool edge was removed in thinning the biface, and then subsequently used as a unifacial piece.

One projectile point in Occupation Horizon 13 is an "ear" to a flaring base Dalton projectile point, manufactured on black Big Fork chert (see Figure 14c). The other is a complete lanceolate (found in situ at $158 \mathrm{~cm}$ bs) made of a honey-colored chalcedony that is probably not of local origin, although the source of the raw material is presently unknown. This lanceolate has rudimentary side notches, pronounced ears, and a shallow basal concavity (see Figure 14d). The blade margins have been alternately beveled, but with resharpening only at an initial stage. The point resembles projectile points from the ca. 10,000 B.P. (uncalibrated) Rex Rodgers bison kill at Mackenzie Reservoir, Texas (Hughes and Willey 1978:Figure 12) and Brazos Fishtail forms from Horn Shelter on the Brazos River in Central Texas (Redder 1985).

There are two end-side scrapers in the assemblage. Both have well-defined, steep working margins on a formalized ovate-shaped flake (see Figure 14f-g). One scraper was made on Woodford chert, while the other is on a heat-treated flake of banded yellow-brown-red chert of unknown provenance.

A large quartzite adze (see Figure 14a) is a distinctive and one-of-a-kind specimen in the Occupation Horizon 13 tool sample from the Quince site. It is on a grayish-green quartzite flake whose lateral margins 


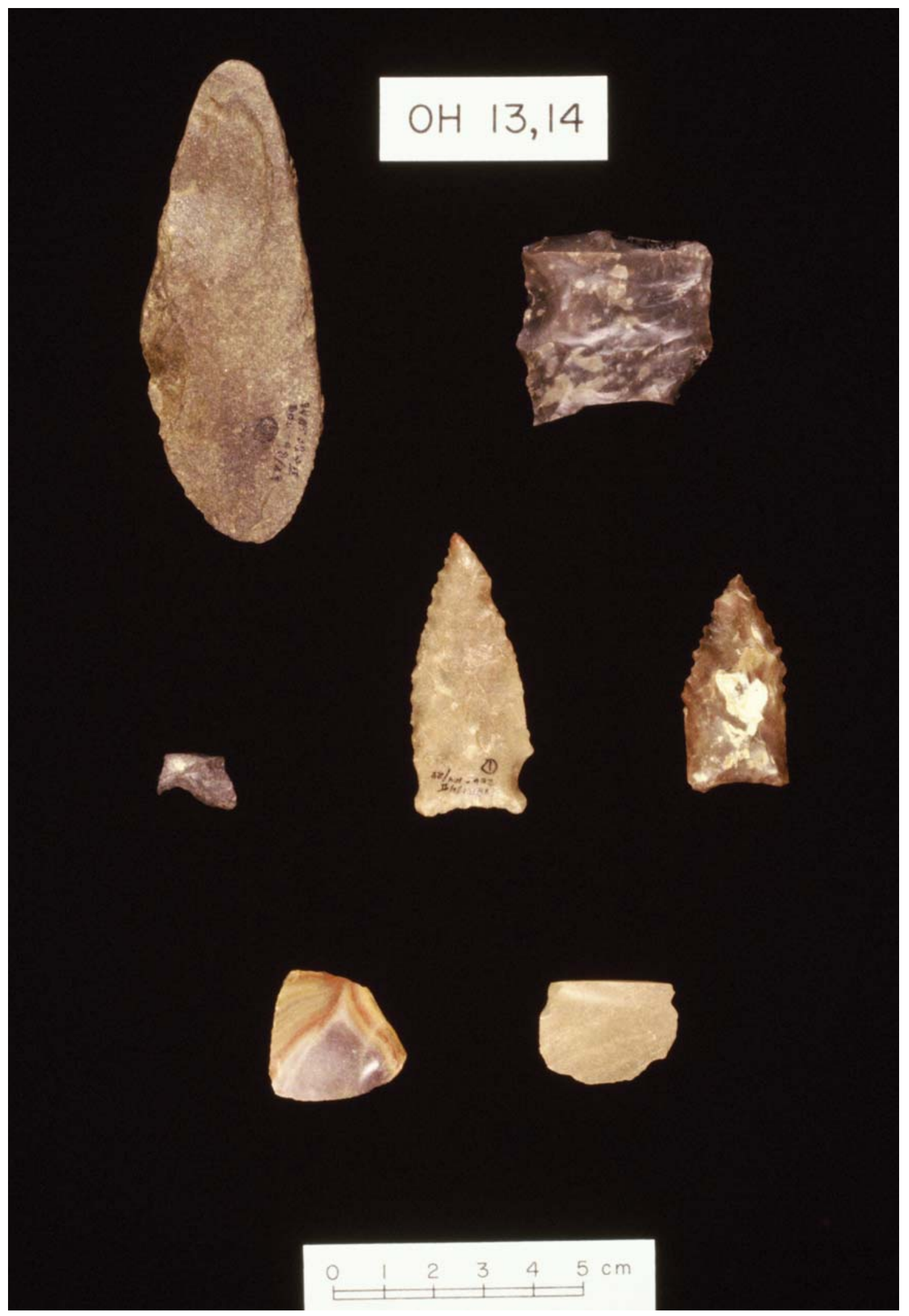

Figure 14. Tools from Occupation Horizons 13 and 14 at the Quince site: a, adze; b, thick biface; c, Dalton projectile point fragment; $d$, lanceolate projectile point with rudimentary side notching; e, petrified wood lanceolate point from Occupation Horizon 14; f-g, end-side scrapers. 
and surfaces are characterized by heavy grinding and polish that extends from the working edge across the remainder of the tool. The lateral and surface polish indicate that this tool had been hafted to produce a heavyduty scraping implement on the coarse-grained local quartzite. Similar implements have been recovered in Late Paleoindian and Early Archaic occupations in the Ouachita River valley of southwestern Arkansas, and they are probably analogous to the Dalton adze found more commonly in the Central Mississippi Valley (Morse and Morse 1983; Morse 1997).

\section{Occupation Horizon 14}

Only a single chipped stone tool is associated with this horizon. It is a lanceolate projectile point made of a high quality and lustrous petrified wood (see Figure 14e). It was found in situ at ca. $161 \mathrm{~cm}$ bs in association with one large burned sandstone cobble.

The point is complete, but extensively resharpened on the blade, with parallel haft margins with a slight concavity, and with lateral and basal grinding (see Figure 14e). One edge of the base has been thinned by removing a series of long, parallel, ovate flakes that originate from the proximal edge, and terminate in small hinges 13-18 $\mathrm{mm}$ from the extant proximal edge. The other side is not thinned, but has been shaped by the removal of multiple, small, ovate flake scars that have been partially obliterated by basal grinding. Cortex remnants on the obverse and dorsal surfaces suggest it was made on a large tabular flake blank.

\section{“Occupation Horizon 15"}

Two chipped stone lithic tools and a single core were recovered in this deepest horizon, ca. $180-210 \mathrm{~cm}$ bs, at the Quince site. One is a thick biface that had been broken during manufacture. Another is a unilateral obverse retouched piece made on a large bifacial thinning flake. This thinning flake had been removed from the base of a ground biface, and then used as a unifacial tool. The final item is a gray-white chert core fragment. Several large parallel flakes had been removed from the stone mass before the core fragment was detached. The gray-white chert has a weathered, chalky cortex, almost certainly is of non-local origin, and the raw material is not represented in the lithic tools or debris in the other Late Paleoindian occupation horizons at Quince.

\section{USE OF LITHIC RAW MATERIALS IN THE CHIPPED STONE TOOLS AND CORES IN COMPONENT V}

The lithic raw material most frequently chosen for chipped stone tool manufacture in the Late Paleoindian occupation horizons at the Quince is chert from local bedrock and gravel sources of the Jackfork and Johns Valley shale formations (Banks 1990:Figure 1.20). According to Banks (1990:46), the Johns Valley formation "is perhaps the most important single source of chert in the western Ouachitas." There are several areas of Johns Valley shale deposits not far from the Quince site (Perttula 1994:Figure 3.1), and abundant chert and quartzite are common in the older alluvial deposits at the site.

Overall, Ouachita Mountains cherts of various kinds were used in the production of 83.1 percent of the chipped stone tools and cores from Component V archaeological deposits at the Quince site (Table 2). This is followed by the local grayish-green and coarse-grained quartzite (10.5 percent), available in the Jackfork formation as well as local gravels, novaculite (2.9 percent), and various other rare raw materials, among them petrified wood, jasper, chalcedony, and siliceous shale. Novaculite and Woodford chert outcrop along Black Knob Ridge in the Muddy Boggy drainage, about 16 km west of the Quince site (Banks 1990:39 and Figure 1.20) 
Table 2. Raw material use in the Component $V$ chipped stone tools and cores.

\begin{tabular}{|c|c|c|c|c|c|}
\hline $\begin{array}{l}\text { Occupation } \\
\text { Horizon }\end{array}$ & Chert & Quartzite & Novaculite & Other* & $\mathrm{N}$ \\
\hline $9 \mathrm{~A}$ & $94.7 * *$ & - & 5.3 & - & 19 \\
\hline 9B & 80.0 & 18.0 & 2.0 & - & 50 \\
\hline 10 & 83.6 & 10.9 & 1.8 & 3.6 & 55 \\
\hline 11 & 90.9 & 9.1 & - & - & 22 \\
\hline $\begin{array}{l}\text { Subtotal, upper } \\
\text { horizons }\end{array}$ & 84.9 & 11.6 & 2.1 & 1.4 & 146 \\
\hline 12 & 78.6 & - & 14.3 & 7.1 & 14 \\
\hline 13 & 75.0 & 12.5 & - & 12.5 & 8 \\
\hline 14 & - & - & - & 100.0 & 1 \\
\hline 15 & 66.7 & - & - & 33.3 & 3 \\
\hline $\begin{array}{l}\text { Subtotal, lower } \\
\text { horizons }\end{array}$ & 73.1 & 3.8 & 7.7 & 15.4 & 26 \\
\hline Totals & 143 & 18 & 5 & 6 & 172 \\
\hline $\begin{array}{l}\text { Summary percentage } \\
\text { for Comp. } V\end{array}$ & 83.1 & 10.5 & 2.9 & 3.5 & \\
\hline
\end{tabular}

*other includes jasper, chalcedony, siliceous shale, and petrified wood; **percentage

During the course of the occupation of the Quince site in the Late Paleoindian period, there apparently were changes in lithic raw material use for chipped stone tools and cores. In the earliest occupation horizons $(\mathrm{OH}$ 12-15), while local chert use was high, a wide range of other raw materials were used, including jasper, chalcedony, siliceous shale, and petrified wood, while novaculite use was relatively substantial (7.7 percent) and local quartzite use for tools was quite low (3.8 percent). In Occupation Horizons 9A-11, chipped stone tool use was concentrated on the use of Ouachita Mountains chert (84.9 percent), and there was an increased use of quartzite for tool manufacture (including bifaces, projectile points, unifacial tools, and cores, see Perttula 1994:Table 6.15). Ouachita Mountains quartzite was commonly used by Late Paleoindian Dalton groups for the manufacture of projectile points (Ballenger 2001:Table 2; Galm and Hofman 1984:Table 6). In the case of the Quince site, that use was intensified beginning in $\mathrm{OH} 11$. The common use of local Ouachita Mountains cherts and quartzites in both the projectile points and other tools in all occupation horizons at Quince strongly suggests that the Late Paleoindian inhabitants of the site had a habitual foraging range that was relatively small scale (e.g., Bamforth 2009:155) and focused on quality habitats within and near the Ouachita Mountains.

\section{LATE PALEOINDIAN LITHIC DEBRIS ASSEMBLAGES}

More than 6600 pieces of lithic debris have been recovered from the OH 9A-15 archaeological deposits at the Quince site (Table 3). The highest densities of lithic debris are in $\mathrm{OH} 9 \mathrm{~B}(\mathrm{n}=2274)$ and $\mathrm{OH} 10(\mathrm{n}=1848)$, and approximately 88 percent of the lithic debris from Component $\mathrm{V}$ is from the upper horizons $(\mathrm{OH} 9 \mathrm{~A}-11)$. 
Table 3. Lithic raw materials in the Component V lithic debris.

\begin{tabular}{lcccc}
\hline $\begin{array}{l}\text { Occupation } \\
\text { Horizon }\end{array}$ & Chert & Quartzite & Other* & N \\
\hline $9 \mathrm{~A}$ & $74^{* *}$ & 26 & - & 875 \\
$9 \mathrm{~B}$ & 74 & 26 & - & 2274 \\
10 & 72 & 27 & - & 1848 \\
11 & 73 & 27 & 0.2 & 861 \\
Sub-total, upper & 73.3 & 26.5 & - & 5858 \\
horizons & 80 & 20 & 3 & 401 \\
& 80 & 17 & - & 204 \\
12 & 89 & 11 & 9 & 411 \\
13 & 82 & 9 & 3.0 & 762 \\
14 & 82.8 & 14.3 & 0.5 & 6620 \\
Sub-total, lower & & & & \\
horizons & 74.1 & 25.4 & & \\
\hline Totals for & & & & \\
Component V & & & & \\
\hline
\end{tabular}

*other includes jasper, chalcedony, petrified wood, and siliceous shale

**percentage

Ouachita Mountains cherts were clearly the focus of chipped stone tool knapping in Late Paleoindian period times at the Quince site, in both the lower and upper occupation horizons. As with the chipped stone tools and cores, while local chert use was quite high in the lithic debris in the lower occupation horizons, other raw materials were knapped on site, including jasper, chalcedony, siliceous shale, and petrified wood. The production of quartzite lithic debris was almost twice as common in the upper Component V occupation horizons (26.5 percent) as it was in the lower occupation horizons (14.3 percent). In the chipped stone tools, quartzite use was three times higher in the upper Component V occupation horizons than it was in the lower Late Paleoindian occupation horizons. The overall impression gathered from the lithic tools and debris in the Late Paleoindian archeological deposits is that Late Paleoindian groups that used the Quince site (perhaps during over-wintering, see Ballenger 2001:41) gathered lithic resources within a foraging range encompassing the western Ouachita Mountains and adjacent Gulf Coastal Plain/Red River basin as part of a seasonally-mobile settlement pattern.

\section{LIKELY AGE OF THE LATE PALEOINDIAN OCCUPATIONS AT THE QUINCE SITE}

If the Quince site were being excavated today, rather than 30+ years ago, optically stimulated luminescence sediment samples (see Boulter et al. 2006) could be obtained from the alluvial sediments exposed in stratigraphic profiles in the Quaternary terrace deposits to establish their age (or at least the last time the sediments were exposed to luminescence), and thus provide at least a temporal bracketing for the various Late Paleoindian occupations buried in the alluvial deposits. Similarly, today, accelerator mass spectrometry dating of minute bits of wood charcoal or charred nutshells in the Component V deposits would likely produce absolute calibrated ages (see Reimer et al. 2004) for these materials. Unfortunately, these dating methods were not available at the time the Quince site was being excavated, and no radiocarbon dates were obtained from Component V at the Quince site. ${ }^{3}$ Charred plant remains of any kind were extremely rare in 
the archaeological deposits, and they were virtually non-existent in association with the few burned rock features documented in the Late Paleoindian component.

It is estimated that the Late Paleoindian component at the Quince site dates from ca. 9800-10,500 years B.P. (ca. 11,200-12,590 calibrated years B.P.). This is based primarily on the well-dated Dalton and San Patrice component at the deeply stratified Big Eddy site in the Ozark Highlands of southwestern Missouri (Lopinot et al. 1998, 2000, 2005; Ray et al. 1998). Radiocarbon dates obtained by Wyckoff $(1985,1989)$ from the Packard site suggest that "Dalton material culture persisted in use to nearly 9500 years ago" (Wyckoff 1999:47). A few of the projectile points recovered in OH 9B and OH 10 also suggest some use of the site between ca. 8000-9000 years (see Figures 91 and 10a-b), and these points may have been derived from overlying Component IV archaeological deposits.

\section{NATURE OF THE PALEOINDIAN OCCUPATIONS}

The Late Paleoindian occupations at the Quince site are situated within a long, narrow alluvial terrace adjacent to McGee Creek, a major tributary in the western Ouachita Mountains of Muddy Boggy Creek in the Red River basin (see Figures 1 and 3). These deposits are found at the southernmost part of the terrace, overlooking the confluence of an intermittent tributary with McGee Creek. Based on the depositional context of the Component $\mathrm{V}$ archaeological deposits, the Late Paleoindian occupations appear to have been situated on the floodplain of McGee Creek.

Block excavations exposed small portions of a number of sequent Late Paleoindian occupation horizons between ca. 110-210 cm bs, although there were also very sparse archaeological materials below those depths. Although it is difficult to estimate the size or internal spatial composition of the different occupation horizons, the distribution of chipped stone tools, lithic debris, burned rock, and burned rock features (Perttula 1994:Figures 7.31-7.50 and Table 7.3) at the Quince site suggest that these occupations probably ranged in size from ca. 100-500 $\mathrm{m}^{2}$. These occupations appear to have been oriented around clusters of burned rock or burned rock features, with "evidence of discrete adjacent refuse disposal, tool discard of broken or unusable implements, differentiation in lithic production activities, and an overall arrangement in a circular pattern adjacent to the hearth" (Perttula 1994:255). The fine-grained spatial patterning seen in the clustering of lithic tool manufacturing areas, tool use and/or discard areas, and the segregation of different lithic raw material reduction activities, suggest that the Late Paleoindian occupations are the product of a series of short-term occupational episodes.

The Late Paleoindian tools and cores from the Quince site are indicative of a relatively diverse assemblage of bifacial and unifacial tools in use, including thick and thin bifaces broken during manufacture (and possibly also in use), end and side scrapers, bifacial Quince scrapers, projectile points, and minimally exhausted cores. Both on-site tool production of projectile points and the maintenance of bifacial tools that may have been made elsewhere were important activities during the different Late Paleoindian occupation horizons (Figure 15a), particularly bifacial tool manufacture, resharpening, and recycling (see Wyckoff 1999:50-51), as was the scraping and processing of hides and other materials (Figure 15b) during game animal processing and procurement activities. The presence of several hafted bifacial Quince scrapers and a quartzite adze suggests that heavy-duty scraping and hide preparation tasks were carried out during $\mathrm{OH}$ 9B, $\mathrm{OH} 10$, and $\mathrm{OH} 13$.

The predominance of hunting and scraping implements in the Late Paleoindian tool assemblage at the Quince site (see Table 1) suggests that the occupations here had a major focus on hunting and the processing of game animals. Projectile points comprise 21.5 percent of the tools in Component V, while scrapers, an adze, and multi-purpose unifacial retouched pieces account for another 41 percent of the assemblage. The Late Paleoindian component at the Big Eddy site, with a large tool sample, by contrast, has been interpreted as a lithic workshop area (Lopinot et al. 1998:201). There, only 4.5 percent of the tools are projectile points 

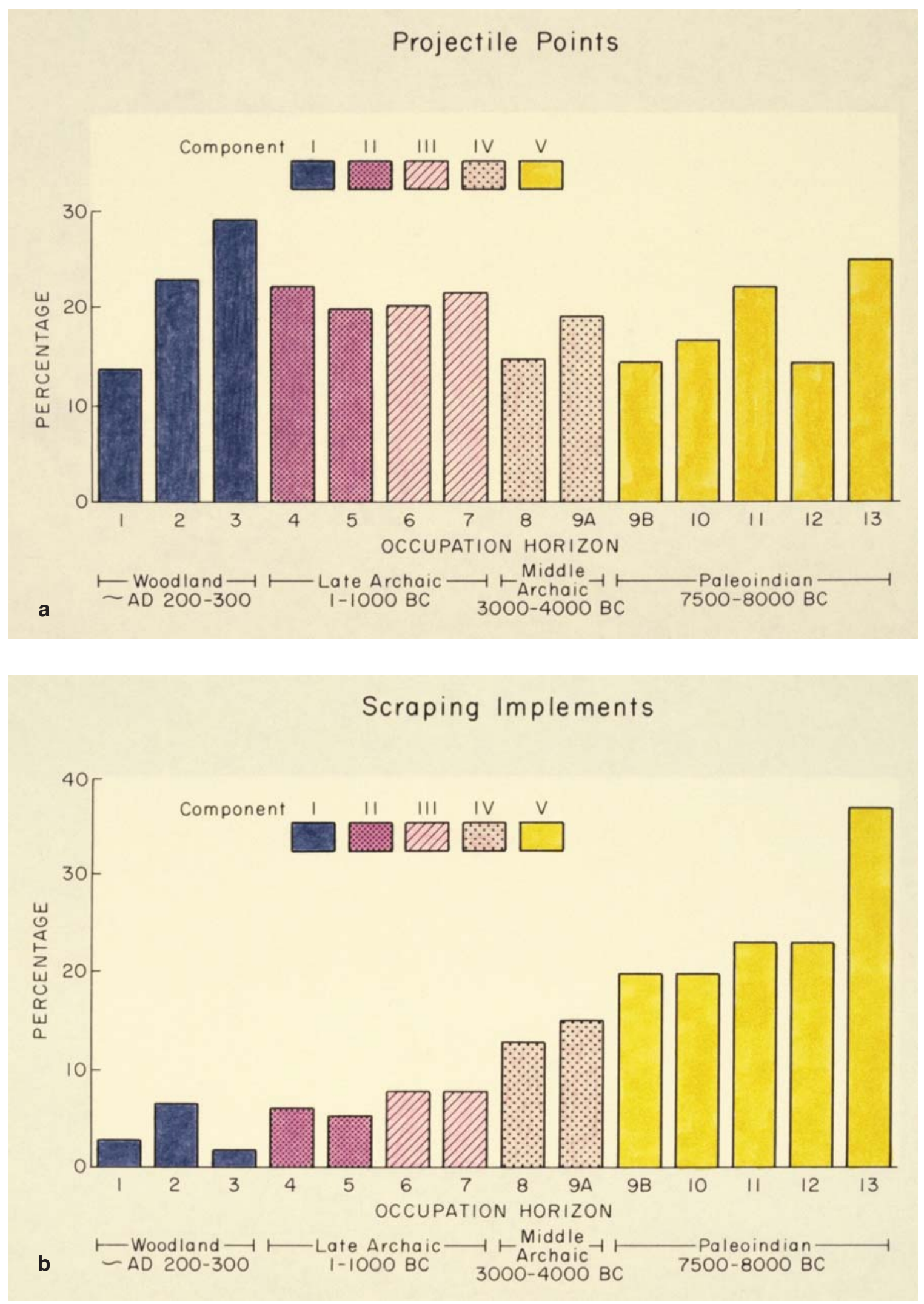

Figure 15. Characteristics of the different prehistoric components (Components I-V) at the Quince site: $a$, projectile point percentages; $b$, percentage frequency of scraping tools. 

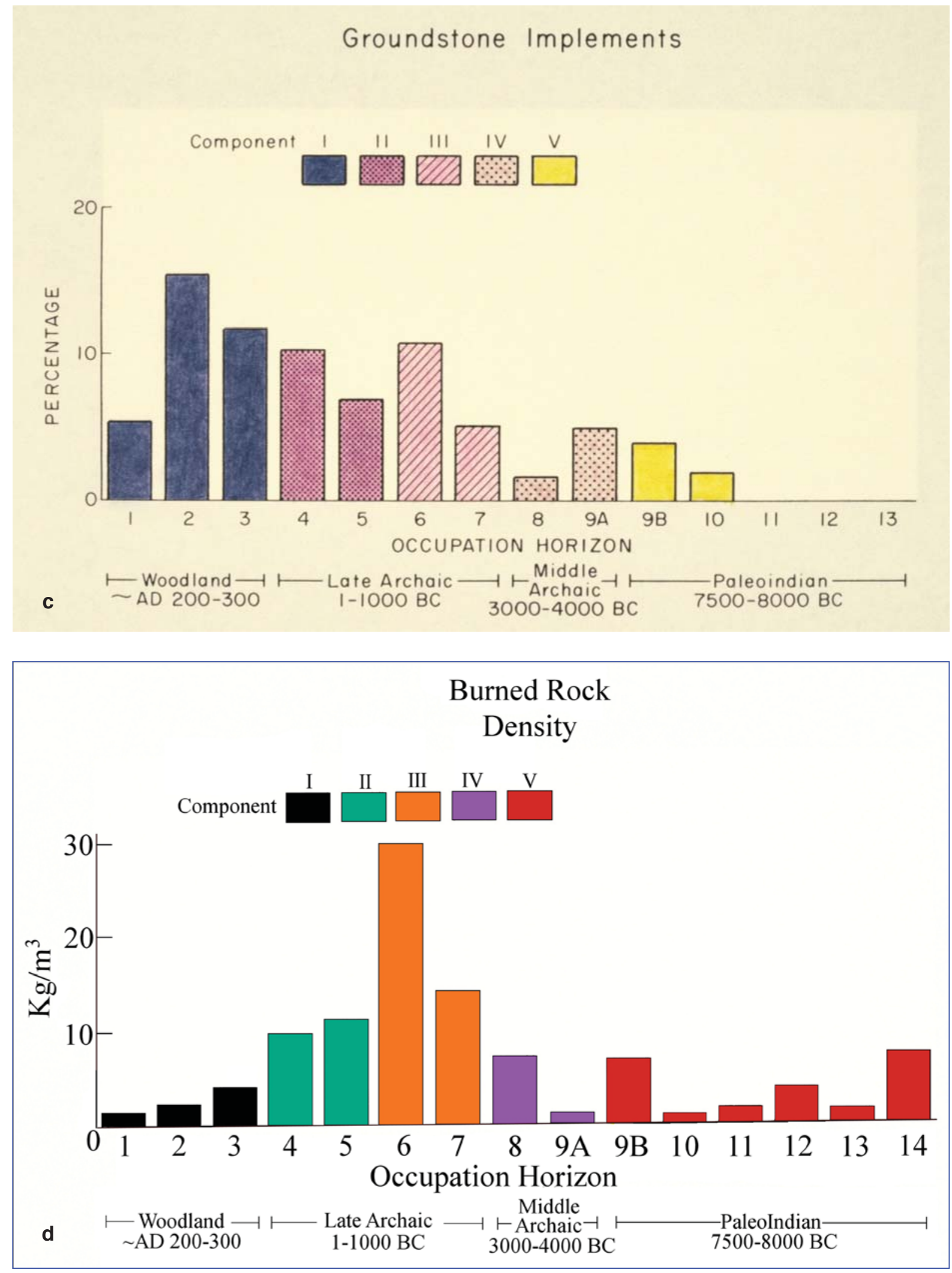

Figure 15. Characteristics of the different prehistoric components (Components I-V) at the Quince site: c, percentage frequency of ground stone tools by occupation horizon tool assemblages; $d$, changes in burned rock density $\left(\mathrm{kg} / \mathrm{m}^{3}\right)$ between Occupation Horizons 1-14. 
(Lopinot et al. 1998:Table 8-6); 33 percent of the tool are scrapers, unifacial tools, and an adze. The most common chipped stone tool at Big Eddy is the biface (61.8 percent); bifaces represent only 36.8 percent of the tools in the Late Paleoindian archaeological deposits at the Quince site.

Ground stone implements in the Late Paleoindian archaeological deposits include only hammerstones and a few metate fragments (see Table 1), which sharply contrasts with the relative frequency of ground stone tools in the Late Archaic and Woodland period occupations (Figure 15c). In these later occupations at the Quince site, plant food processing tools such as metates, manos, and pitted stones were important tools related to the processing by stone boiling and hot-rock cooking of plant foods collected in the surrounding oak woodlands. Consequently, the density of burned rock through time peaked in $\mathrm{OH}$ 4-7 in the Late Archaic, and was very much diminished in the Late Paleoindian occupation horizons (Figure 15d).

\section{PROJECTILE POINT DIVERSITY IN LATE PALEOINDIAN CONTEXTS}

The diversity in the form of lanceolate projectile points from the Quince site, as well as other Late Paleoindian sites in the western Ouachita Mountains, is probably the product of stylistic and morphological differences in local projectile point production, as well as distinctive traditions of use and reuse (beveling and resharpening, see Wyckoff 1999:51) from a series of culturally related Late Paleoindian or Dalton occupations over almost a 1400 year period (in calibrated years B.P.). Are there formal differences in the lanceolate points from the different occupation horizons at the Quince site? And if there are stylistic variations, are they indicative of changes in Late Paleoindian projectile points through time?

By depth and occupation horizon, the apparently oldest lanceolate point at the Quince site is one from $\mathrm{OH} 14$ that has parallel-sided stem edges with a slightly concave base (see Figure 14e). Wyckoff (2005a) calls this form 'Plainview-like," while Johnson (1989:18 and Figures 6 and 7a) dubs this the lanceolate variety of Dalton. This particular lanceolate form is common at the Bell site (Wyckoff 1968:Plate V.2-4) as well as in the McKellips locality (Ballenger 2001:Figures 14 and 15), and Johnson (1989:19) argues that the lanceolate variety of Dalton is more frequent in Late Paleoindian sites along the prairie-woodland edge. At the Quince site, this particular form of Dalton is also present in $\mathrm{OH} 9 \mathrm{~B}, \mathrm{OH} 10$, and $\mathrm{OH}$ 11, suggesting that the lanceolate variety of Dalton was made and used throughout the Late Paleoindian occupation.

A lanceolate form with an expanding stem edge and a flaring and slightly concave base (and small flaring basal ears) is present in $\mathrm{OH} 13$ at Quince, and also occur in low frequencies in the McKellips, Billy Ross, and Dirty Creek localities (see Ballenger 2001:Figures 14-17); this form is absent at the Bell site. The classic Dalton point with strongly concave stem edges and base, as well as flaring basal ears, is also present in $\mathrm{OH} 13$, as well as in $\mathrm{OH} \mathrm{9B}$, suggesting more than one form of Dalton point was in use at the same time. This form is particularly common in eastern Oklahoma Late Paleoindian projectile point assemblages. In later occupation horizons at the Quince sites, the lanceolates range from points with parallel stem edges and very concave bases $(\mathrm{OH} 9 \mathrm{~B})$, to forms with expanding stem edges and very concave bases $(\mathrm{OH} 9 \mathrm{~A})$, and to lanceolate points with expanding stem edges and only slightly concave bases (OH 12); none have flaring basal ears.

If Johnson (1989:18) is correct in stating that different stem forms of Dalton-related lanceolates reflect both "different ways of affixing dart heads to foreshafts" as well as "slight stem changes through time," then it would seem that during the Late Paleoindian occupation at the Quince site that several hafting methods were employed. These methods were designed to accommodate lanceolate points with flaring bases and basal ears as well as points with both parallel and expanding stem edges and a range of basal concavities. The occurrence of lanceolate points with different hafting methods in the same occupation horizons clearly would seem to indicate that these different hafting methods may have been contemporaneously or near contemporaneously used in this Late Paleoindian context, given the vagaries of artifact deposition, and that there would not seem to be clear temporal trends in stem form. This in turn would seem to suggest that 
these lanceolate projectile point forms were part of a single tradition or assemblage of Late Paleoindian point styles. These conclusions could readily be turned on their heads if well-dated single component and/ or stratified assemblages of Late Paleoindian projectile points were to be found and investigated in eastern Oklahoma, but such assemblages have not been identified in the region.

\section{LOCAL AND REGIONAL PALEOINDIAN CONTEXT}

While Early Holocene biotic communities in the McGee Creek area were dominated by grassland species during much of the Quince Paleoindian occupation, it is not clear if the use of McGee Creek at that time was part of a specialized procurement system embedded in a more generalized foraging strategy of forest-based Paleoindians (located to the east in the mountains as well as south in Gulf Coastal Plain habitats, cf. Driskell and Walker 2007), or whether the Paleoindian groups that used the area were grasslands-adapted groups that foraged principally on the grasslands (see Johnson 1989:9-12). In large measure, we are hindered by the absence of preserved faunal and floral remains from Late Paleoindian components in the broader Ouachita Mountains region, including the virtually complete absence of such remains at the Quince site.

Climatic changes during the Late Paleoindian period can be expected to have affected the long-term biotic potential of the region in general, and the western Ouachita Mountains in particular, because of concomitant changes in the distribution and relative abundance of plant and animal resources. Certainly changes in faunal composition, relative species abundance, the kinds and availability of aquatic resources (including birds), and an overall variability in forest habitats at this time from east to west across the mountains (Coleman et al. 2009:Appendix I) would have contributed to different emphases in resource procurement and settlement locational choices for Late Paleoindian groups than had previously been the case.

All known Paleoindian sites and components in the McGee Creek area (Figure 16), including the Quince site, were occupied at a time that coincides with the maximum expansion of the herb-grass-dominated steppe in the western Ouachita Mountains. Forest habitats were apparently limited in extent and diversity, and probably were riparian in character. The Quince site was probably situated within this riparian zone bordering McGee Creek. Throughout the Late Paleoindian era, the only significant changes in the vegetational record was the slow replacement of Ambrosia sp. by grasses as the major constituent of this steppe biotic habitat. The known density (i.e., the frequency of sites standardized to reflect the duration of the different temporal periods, as a measure of the number of components per 100 year intervals, see Perttula 1994:Figure 8.7 and Table 8.3) of Late Paleoindian sites at McGee Creek ( 9 percent of all the sites occupied where their temporal affiliation is known) may reflect these environmental limitations and cooler conditions. Late Paleoindian sites occur significantly less frequently than expected by chance given the length of the period, and conversely the most intensive use of the McGee Creek area in prehistoric times took place during the Woodland and Early Caddo periods. During those times, an oak-hickory forest was established, encroaching on the prairie, eventually followed by a stable oak-hickory-pine forest that was similar to present-day vegetational conditions.

The dominance of grass communities from ca. 11,000 to 10,000 years B. P. (ca. 12,915-11,400 calibrated years B.P.) suggests that climatic conditions during the Late Paleoindian period in the western Ouachita Mountains were drier and colder than they were at the end of the Late Glacial period (ca. 12,000 years B.P., or ca. 13,834 calibrated years B.P.). The Early Holocene environment may also have been drier and cooler than was the case in the Middle Holocene (ca. 8000-5000 years B.P., or ca. 8900-5700 calibrated years B.P., see Anderson et al. 2007). At the end of the Late Paleoindian period, there is no evidence in the paleoenvironmental record for changes in vegetation that denote declining conditions or changes in overall exploitation potentials. Rather, there were likely modest increases in the density of oak that suggests that the environment at the Late Paleoindian-Early Archaic transition was characterized by an increase in food resource availability to mobile hunter-gatherers returning again to the western Ouachita Mountains. 


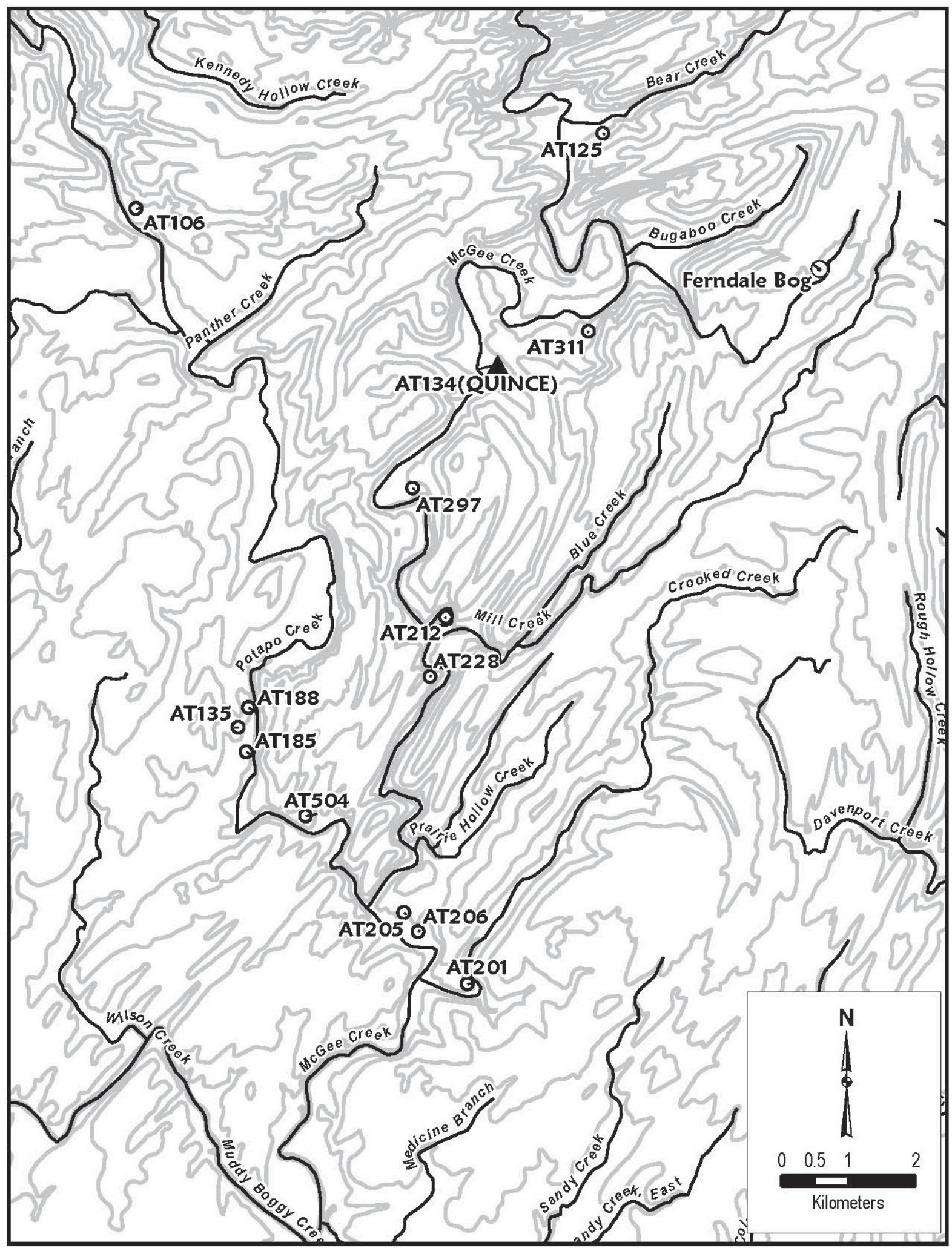

Figure 16. Late Paleoindian sites in the McGee Creek Reservoir project, including Quince (34AT134), and the location of Ferndale Bog. 
At the time of the Component V occupation at the Quince site, the McGee Creek area may have been near the forest-prairie ecotone. As such, the western Ouachitas were well-suited for over-wintering or as a place for the establishment of strategically placed seasonal camp sites because of the proximity of water, stone resources, and the availability of a variety of exploitable resources found in prairie and wooded habitats (e.g., Driskell and Walker 2007:235). Reforestation subsequent to 9000 years B.P. (10,200 calibrated years B.P.) would have led to an increase in edge habitats favorable to woodland species as well as an expansion of arboreal resources. The overall biotic potential of the McGee Creek area would have been greater after 9000 years B.P. than what was the case at the time of the Late Paleoindian occupations.

Components of the Late Paleoindian period in the McGee Creek area occur primarily on Pleistocene or early Holocene relict terraces about $8 \mathrm{~m}$ above the present creek level (Table 4; see also Figure 17). In most cases, these landforms represent stable or net erosional surfaces throughout most of the Holocene, and later occupational materials are also found within the shallow deposits in these settings. Other Late Paleoindian components are situated on high bluffs, ridge crests, ridge slopes, and upland saddles. With few exceptions, sites in these settings contain diagnostic Late Paleoindian artifacts in mixed multi-component assemblages.

Table 4. Other Late Paleoindian sites in the McGee Creek Reservoir area.

\begin{tabular}{|c|c|c|c|c|c|c|}
\hline Site & Drainage & Landform & Dalton & Lanceolate & $\begin{array}{l}\text { Quince } \\
\text { scraper }\end{array}$ & Drill \\
\hline 34AT106 & Potapo Creek & QAT & $\mathrm{x}$ & & & \\
\hline 34AT125 & Bear Creek & QAT & $\mathrm{x}$ & & & \\
\hline 34AT135 & Potapo Creek & Saddle & $\mathrm{x}$ & $\mathrm{x}(\mathrm{SN})$ & & \\
\hline 34AT185 & Potapo Creek & QAT & $\mathrm{x}$ & $\mathrm{x}(\mathrm{SN})$ & & \\
\hline 34AT188 & Potapo Creek & Ridge slope & $\mathrm{x}$ & $\mathrm{x} \& \mathrm{SN}$ & $\mathrm{x}$ & \\
\hline 34AT201 & Crooked Creek & QAT & $\mathrm{x}$ & $\mathrm{x}(\mathrm{SN})$ & & \\
\hline 34AT205 & McGee Creek & QAT & $\mathrm{x}$ & $\mathrm{x}$ & $\mathrm{x}$ & \\
\hline 34AT206 & McGee Creek & QAT & $\mathrm{x}$ & & $\mathrm{x}$ & \\
\hline 34AT212 & McGee Creek & $\begin{array}{l}\text { QAT, ridge } \\
\text { crest }\end{array}$ & $\mathrm{x}$ & $\mathrm{x}$ & $\mathrm{x}$ & $\mathrm{x}$ \\
\hline 34AT220 & McGee Creek & Point bar & & $\mathrm{x}$ & & $\mathrm{x}$ \\
\hline 34AT297 & McGee Creek & QAT & $\mathrm{x}$ & & & \\
\hline 34AT311 & McGee Creek & $\begin{array}{l}\text { QAT, ridge } \\
\text { slope }\end{array}$ & $\mathrm{x}$ & & & \\
\hline 34AT504 & Potapo Creek & Ridge slope & $\mathrm{x}(?)$ & & & \\
\hline
\end{tabular}

x=present; QAT-Quaternary alluvial terrace; SN=side notched point; see Ferring et al. 1994a, 1994b; Hackenberger and Cheek 1976; McGuff 1993; McGuff et al. 1983; Perttula and McGuff 1993 for information about the sites.

In a few instances, however, there are Late Paleoindian components that appear to be relatively horizontally discrete, including the Green Snake site (34AT106, Block B, see Ferring et al. 1994b; McGuff 1993:19-26; McGuff et al. 1983:4-17 to 4-21) and the Feeder site (34AT188, see Ferring et al. 1994a:257271). Both assemblages contain a low density of primarily chert lithic debris and tools (several of novaculite or a blue-gray brecciated chert) that indicate an emphasis on the hunting and processing of game animals, along with the production and maintenance of chipped stone tools. Ground stone tools or burned rock are absent, and the most common tool types include hafted bifaces, scrapers (including Quince scrapers), and unifacial tools (Figure 17a-c). At the Feeder site, projectile points included an unidentified lanceolate form, two final stage Dalton points, and a resharpened Graham Cave side-notched point. At the Green Snake site, the projectile points found were basally ground Dalton lanceolates with concave bases and ears, extensive blade resharpening, and basal grinding (see McGuff 1993:Figure IV.3i). 


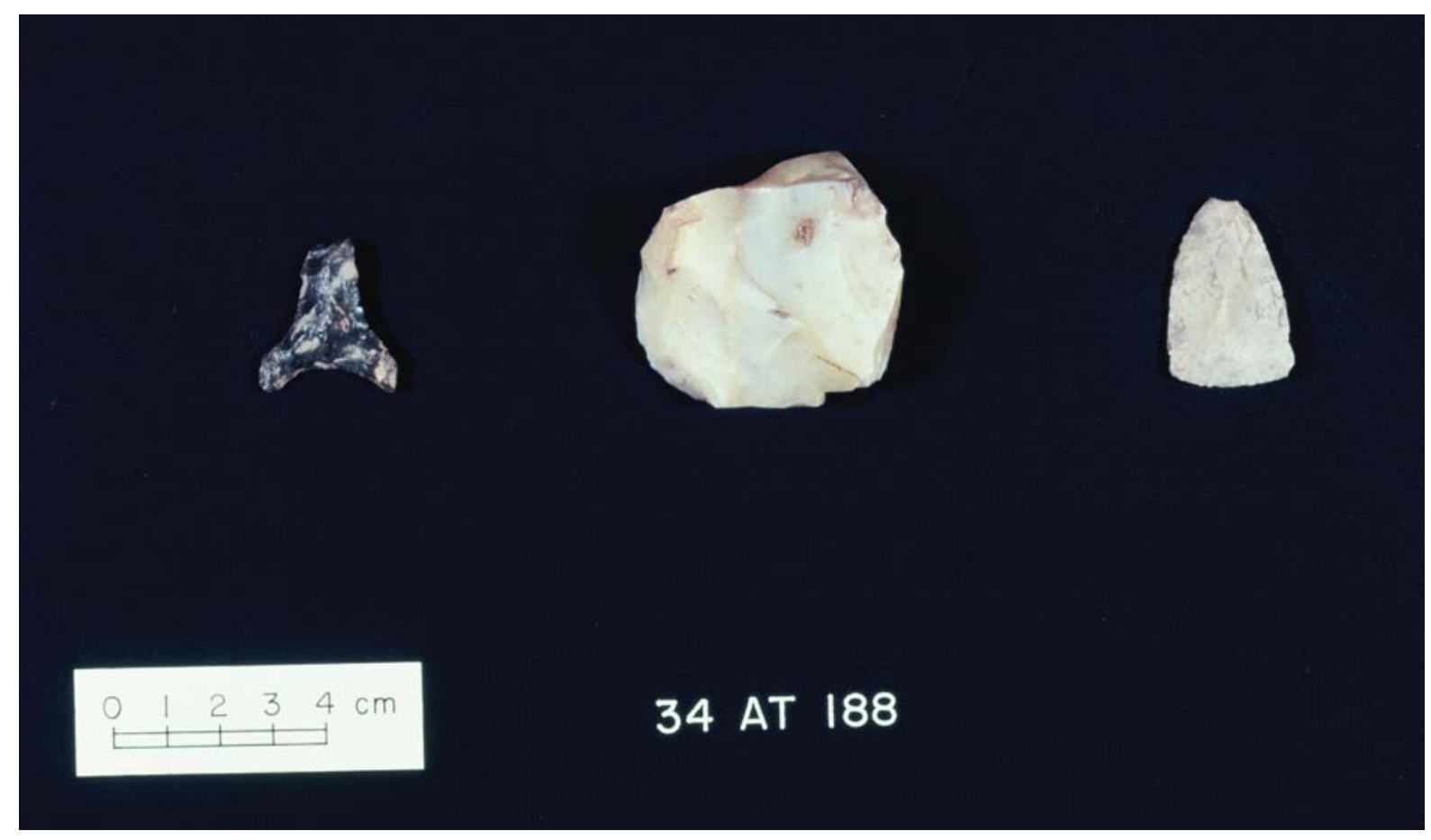

Figure 17. Late Paleoindian tools from the Feeder site (34AT188): a, Dalton point, final-stage; b, large scraper; c, Quince scraper.

The Dry Bone-Ambrose Bierce site (34AT212) has an extensive Late Paleoindian chipped stone tool assemblage, although a discrete component could not be recognized in the shallow alluvial terrace and ridge crest archaeological deposits (Ferring et al. 1994a:165-196). The Late Paleoindian chipped stone tools include initial to final stage Dalton points and other lanceolates (Figure 18c-k), bifacial and unifacial scraping tools, and three Quince scrapers (Figure 18a-b).

Late Paleoindian groups established camps in a number of different habitats within the Ouachita Mountains and Arkoma Basin, including the floodplain, as in the case of the Quince site, the Bell site (Wyckoff 1968), and the Billy Ross locality along San Bois Creek (Ballenger 2001:26). In most cases, the archaeological remains for this period occur as isolated artifact finds or occur in mixed multi-component assemblages. For example, the Mahaffey (Rohrbaugh et al. 1971; Perino and Bennett 1978), McKensie, Hill (Rohrbaugh 1972), Bill Hughes, Biggham Creek (Wyckoff 1967a), McKellips (Ballenger 2001:26), and Green Snake sites are found on very high and ancient alluvial terraces away from present stream courses. Other sites are known in the uplands, along ridge slopes, ridge toes, and saddles, including the Feeder site, 34PU101 (Wyckoff 2005a:31), and the Dirty Creek locality (Ballenger 2001:27). Woods Mound Group (Wyckoff 1967b) and 34MC151 (Gettys 1975) are on high bluffs overlooking major stream floodplains.

The archaeological deposits at the Bell site (34MC76) on the Little River (Wyckoff 1968) share several archaeological and geoarchaeological characteristics with the Quince site. ${ }^{4}$ Both sites contain Late Paleoindian archaeological materials buried in the deep alluvium of narrow Ouachita Mountains river valleys, and both are situated immediately upstream of the mouths of small tributary streams (see Figure 16; Wyckoff 1968:Figure 2). Most of the lanceolate projectile points from the Bell site-one with a flaring base (Wyckoff 1968:Plate V.1), and three with parallel-sided stems and slightly concave bases (Wyckoff 1968:Plate V.2-4) - are morphologically comparable to points from Occupation Horizons 9B, 10, 11, and 14 at the Quince site. The fifth lanceolate point at the Bell site has a contracting stem (Wyckoff 1968:Plate V.5), and is similar to other lanceolate points from sites in eastern Oklahoma (Wyckoff 1985, 2005a:Figure 4). Additionally, the same kinds of lithic raw materials, most notably the 


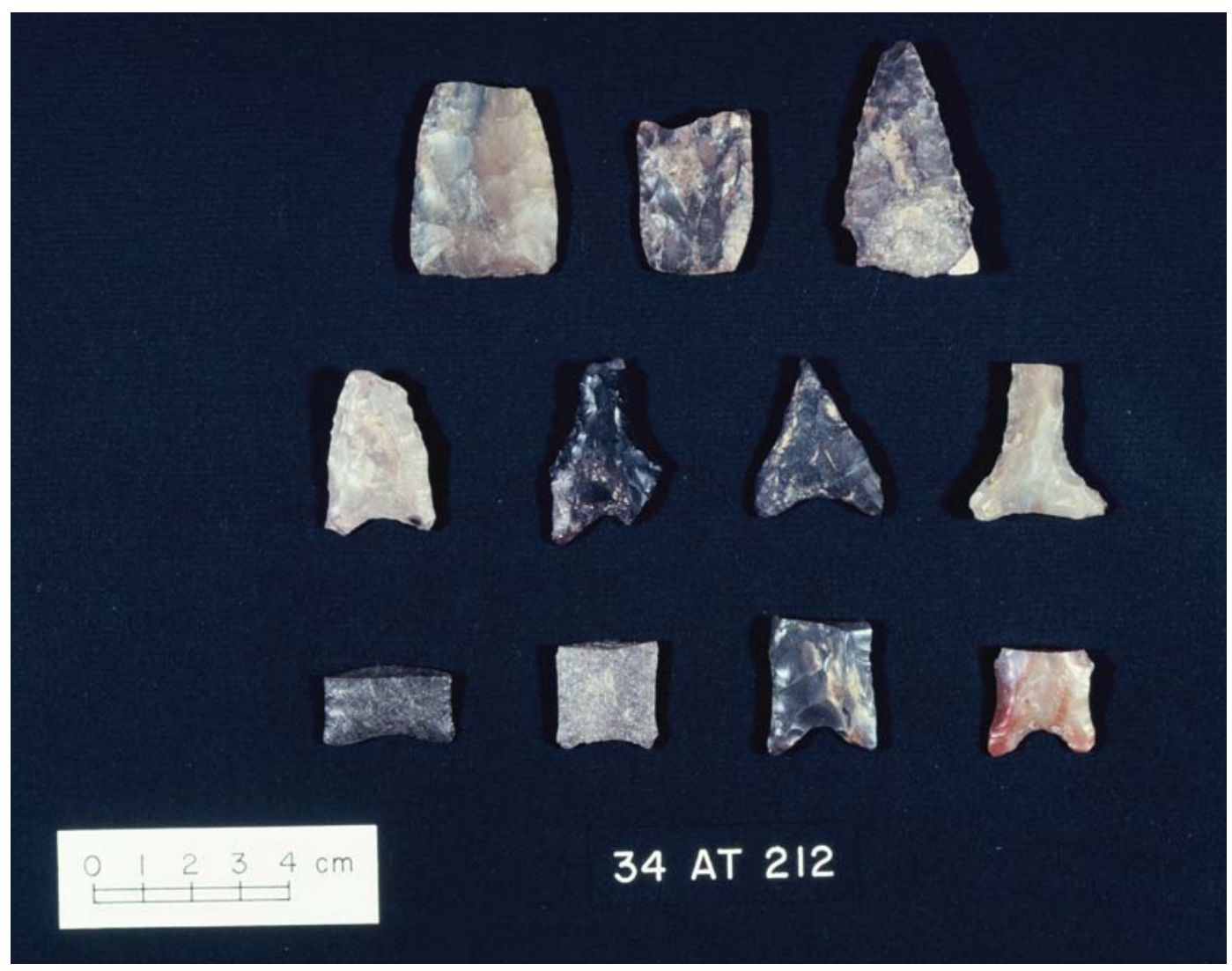

Figure 18. Late Paleoindian projectile points and Quince scrapers from the Dry Bone-Ambrose Bierce site (34AT212): a-b, Quince scrapers; c, broad-bladed, parallel stemmed, and concavebased lanceolate; d, h-i, Dalton point, lanceolate variety; e, g, Dalton point, final stage; f, j-k, Dalton point.

Ouachita Mountains quartzites, were used in the production of the Late Paleoindian points at both the Quince and the Bell sites.

The geomorphological, stratigraphic, and sedimentological context of the Quince and Bell sites are apparently much the same, although they are situated on two different mountain drainages separated by more than $75 \mathrm{~km}$. At both locations, Pleistocene-age alluvium was truncated, and in a subsequent period of stability a strong soil with a yellowish-red argillic B-horizon developed. At the Quince site, this argillic horizon was not exposed in the $3 \mathrm{~m}$ deep excavations, and it was only exposed at the Bell site in Grid B on a higher landform (Wyckoff 1968:Figure 4). Archaeological materials have not been found in this truncated B-horizon, but because archaeological deposits found immediately above it date from ca. 10,500-9,500 years B.P., it appears that these land surfaces stabilized sometime prior to ca. 10,000 years B.P. Beginning shortly before ca. 10,000 years B.P., there appears to have been a relatively rapid aggradation of sandy alluvium in floodplain areas along the Little River and McGee Creek. This deposition resulted in the burial of Late Paleoindian artifacts and features in thick $(1-2+\mathrm{m})$ alluvium, as well as archaeological deposits with very low artifact densities (Wyckoff 1968:Table XX; Perttula 1994:Table 6-12). Soil genesis subsequent to the Late Paleoindian occupations in these sandy sediments is indicated by the illuviation of silt and clay-sized particles in distinct lamellae over $30 \mathrm{~cm}$ in thickness. The depositional and hydrological events recorded at the Bell and Quince sites appear to reflect important paleoenvironmental changes that were regional in scale in that key erosional, depositional, and soil-forming events can be correlated between two widely separated locales in the Ouachita Mountains where Late Paleoindian archaeological deposits have been found in good stratigraphic context. 
Overall, the range of tools and habitation debris on Late Paleoindian sites in southeastern and eastern Oklahoma is consistent with the notion that they represent small camps or places used by mobile foragers with an unspecialized hunting and processing tool kit. This tool kit seems consistent with aboriginal groups that had a generalized hunting and gathering subsistence strategy, rather than one more appropriate for big game or specialized economic pursuits. This is not to suggest that seasonally specialized economic pursuits may not have been part of Late Paleoindian subsistence strategies, as would be indicated by assemblages dominated by projectile points, Quince bifacial scrapers, end scrapers with graver spurs, and other hunting and processing-related tools, as seems to be the case at the Quince site and other still poorly known sites in the Ouachita Mountains and western Gulf Coastal Plain (see Lorrain and Hoffrichter 1968:8-53; Rohrbaugh 1972; Baugh and Hofman 1979).

Patterns of lithic raw material utilization for chipped stone tools suggests that the exploitative range or band movements of these Late Paleoindian groups as a whole primarily included the Ouachita Mountains, the Ozark Highlands, the Arkoma Basin, as well as parts of the western Gulf Coastal Plain, including the Red River valley south of the Ouachita Mountains. The Quince site chipped stone tools point to a relatively localized foraging range. For the moment, and until more detailed studies of Dalton technology can be done on sites in the region with discrete and dated Late Paleoindian archaeological deposits, the model of settlement proposed by Ballenger (2001:41) would appear to be a reasonable summation of the available archaeological evidence:

A generalized routine of Dalton settlement is argued to have involved overwintering camps in the Ozark and Ouachita mountains; spring and summer camps along major valleys such as the Arkansas River, the Illinois River in the Ozarks, and the Kiamichi River in the Ouachitas; and fall aggregation in the Arkoma Basin.

\section{CONCLUSIONS}

A notable series of Late Paleoindian, Archaic, and Woodland period occupation horizons that were buried in deep alluvial sediments were documented and studied in 1982 and 1983 archaeological excavations at the Quince site (34AT134), along McGee Creek, in the McGee Creek Reservoir (Perttula 1994) in southeastern Oklahoma; the site is now underwater. In this article, I have focused on the Late Paleoindian (ca. 10,500-9800 years B.P. or 12,600-11,220 calibrated years B.P.) occupation horizons (OH 9A-15) at the site because they provide important archaeological evidence from stratified deposits for the long-term and recurrent use of the western Ouachita Mountains by mobile hunter-gatherers during this time of significant climate change, when the western Ouachita Mountains were not forest-covered, but were a grass and herb prairie. Buried and/or stratified Late Paleoindian sites remain poorly documented in the Ouachita Mountains (see Wyckoff $1968,1984,1999,2005 a)$, and the Quince site is one of a very few such sites known in the region.

The Late Paleoindian archaeological deposits at the Quince site, found below $1.1 \mathrm{~m} \mathrm{bs}$, are marked by a series of occupation horizons with scattered chipped stone tools, cores, lithic debris, burned rock, and a few burned rock features. The tools and lithic debris are virtually all the product of the reduction of local Ouachita Mountains chert and quartzite raw materials, which are abundant in gravel sources throughout the McGee Creek drainage. The most distinctive chipped stone tools in the Late Paleoindian occupation horizons are a series of distinctively-shaped lanceolate projectile points and bifacial Quince scrapers, along with an abundance of end scrapers, side scrapers, and unifacial flake tools. The lanceolate points recovered at the Quince site include several Dalton points as well as a number of other lanceolates with parallel or expanding stems, concave bases, lateral and basal grinding, and extensive blade resharpening and beveling.

Because the chipped stone tool assemblage is dominated by hunting and game animal processing tools, many of them broken and discarded during each occupation, it seems reasonable to conclude that the Quince site was a hunting, game processing, and tool refurbishing camp during the entirety of the Late Paleoindian period. It is not known what game animals the Quince site hunters focused their efforts on, but they could 
have been animal species found in both prairie and forest environments, which would have been one of the benefits in living along the prairie-forest ecotone in Late Paleoindian times. When the site was reoccupied in the Middle Archaic period, plant food processing and hot rock cooking of food stuffs became, and remained, the major subsistence activity detected in the archaeological deposits at Quince for several thousand years.

Hopefully, archaeologists interested in the lifeways of the Late Paleoindian inhabitants of eastern Oklahoma and contiguous states will continue efforts to not only document the character of Late Paleoindian artifacts from sites and collections across the region, but also develop archaeological and geoarchaeological research programs to identify and study other buried and stratified sites with Paleoindian deposits along Ouachita Mountains and Ozark Plateau streams. The concerted investigation of such buried and stratified sites, particularly if they are found to contain any preserved plant and animal remains and have deposits that can be directly dated by OSL and AMS, will revolutionize our understanding of the settlement, subsistence, and technological character of the Late Paleoindian aboriginal groups that ranged across what is now eastern Oklahoma.

\section{ACKNOWLEDGMENTS}

The archaeological information discussed in this paper was primarily gathered during the course of the McGee Creek Reservoir project, funded by the Bureau of Reclamation. Dr. C. Reid Ferring was the Principal Investigator for the archaeological investigations, and he was assisted by Paul McGuff as Project Director. I am grateful to both of them for the opportunity to work on the project. I also appreciate the hard work and dedication of the crew at the Quince site during two field seasons, especially the efforts of Gemma Mehalchick, Robert Cast, Donnie Clay, and Tody Clay. Don G. Wyckoff, now of the Sam Noble Oklahoma Museum of Natural History at the University of Oklahoma, shared insights, information, and advice during a field visit in 1983, and in several subsequent conversations about the Late Paleoindian period in the Ouachita Mountains. He also encouraged the preparation of a paper about the Quince site, in large part, I think, because of the unavailability of the technical report submitted to the Bureau of Reclamation, many years after the completion of the field work. Sandra Hannum prepared several of the figures in this manuscript, and I also thank Blake Mitchell for some scanning work. Any errors of fact or interpretation, however, presented herein remain solely my responsibility.

\section{END NOTES}

1. The stratified archaeological deposits at 34PS279 and 34MC837 may be other eastern Oklahoma and Ouachita Mountains sites that have the potential to contain discrete occupation horizons spanning much of the Early Holocene (Brosowske and Vehik 1999; Sundermeyer et al. 2004), although work at both of the sites has been limited. At 34PS279, a calibrated radiocarbon age intercept of 9022 years B.P. $(8120 \pm 330$ B.P., the corrected radiocarbon date) has been obtained from charcoal in deposits between $200-220 \mathrm{~cm}$ bs. A possible lanceolate variety of Dalton point was recovered in the same excavations at a depth of $170-180 \mathrm{~cm}$ bs (Brosowske and Vehik 1999:Figure 7.12). The investigations at 34MC837, on an alluvial terrace along Mountain Fork River, obtained a 2 sigma calibrated age range of 7980-8177 B.P. from buried deposits associated with Feature 2, a burned rock deposit (Sundermeyer et al. 2004:178). In the level below the radiocarbon date was a broad-bladed stemmed dart point with a beveled blade, expanding stem, and slightly concave base (Sundermeyer et al. 2004:Figure 55f). A similar stemmed point has been recovered from $\mathrm{OH}$ 9B at the Quince site (see Figure 91).

2. The analysis of the raw materials represented in the lithic debris from the Quince site-and indeed from all of the McGee Creek Reservoir sites - leaves a lot to be desired, unfortunately. Because of the large numbers of lithic debris pieces recovered from the sites (more than 82,900 pieces were found in the excavations at the Quince site, see Perttula 1994:Appendix III), the basic distinctions made for the lithic debris included only chert and quartzite as raw material options; large vs. small in size; and interior vs. cortical. Other raw materials (novaculite, chalcedony, jasper, petrified wood, etc.) were occasionally noted, but it is my suspicion that much of the other raw 
materials were not consistently or accurately identified in the lithic debris samples, and their absolute frequency is underrepresented. In any event, the other raw materials are not tabulated in the lithic debris descriptive data from the Quince site.

3. Randomly scattered bits of wood charcoal $(0.1 \mathrm{~g})$ from $\mathrm{OH} 9 \mathrm{~B}$ were dated by AMS dating to $315 \pm 75$ radiocarbon years B.P. or 317 calibrated years B.P. (Perttula 1994:Table 5.1). This calibrated date is woefully inaccurate given the context of the wood charcoal.

4. The discussion of Quince and Bell site comparisons originated in a presentation by Perttula et al. (1986) at the 7th Annual Meeting of the Mid-South Archaeological Conference.

\section{REFERENCES CITED}

Albert, L. E., with contributions by D. G. Wyckoff

1981 Ferndale Bog and Natural Lake: Five Thousand Years of Environmental Change in Southeastern Oklahoma. Studies in Oklahoma's Past No. 7. Oklahoma Archeological Survey, Norman.

Anderson, D. G.

2001 Climate and Culture Change in Prehistoric and Early Historic Eastern North America. Archaeology of Eastern North America 29:143-186.

Anderson, D. G., M. Russo, and K. E. Sassaman

2007 Mid-Holocene cultural dynamics in southeastern North America. In Climate Change and Cultural Dynamics: A Global Perspective on Mid-Holocene Transitions, edited by D. G. Anderson, K. A. Maasch, and D. H. Sandweiss, pp. 457-489. Elsevier, Amsterdam.

Ballenger, J. A. M.

1998 The McKellips Site: Contributions to Dalton Occupation, Technology, and Mobility from Eastern Oklahoma. Southeastern Archaeology 17(2):158-165.

2001 Dalton Settlement in the Arkoma Basin of Eastern Oklahoma. R. E. Bell Monographs in Anthropology No. 2. Sam Noble Oklahoma Museum of Natural History, University of Oklahoma, Norman.

Bamforth, D. B.

2009 Projectile points, people, and Plains Paleoindian perambulations. Journal of Anthropological Archaeology 28(2):142-157.

Baugh, T. G. and J. L. Hofman

1979 Division II. In Oklahoma Highway Archaeological Survey, Highway Archaeological Reconnaissance Program 1972-1978, edited by D. R. Lopez and K. D. Keith, pp. 183-418. Papers in Highway Archaeology, No. VI. Oklahoma Highway Archaeological Survey, Norman.

Banks, L. D.

1984 Lithic Resources and Quarries. In Prehistory of Oklahoma, edited by R. E. Bell, pp. 65-95. Academic Press, New York.

1990 From Mountain Peaks to Alligator Stomachs: A Review of Lithic Sources in the Trans-Mississippi South, the Southern Plains, and Adjacent Southwest. memoir \#4. Oklahoma Anthropological Society, Norman.

Binford, L. R.

1983 Working at Archaeology. Academic Press, New York.

Boulter, C. H., M. D. Bateman, C. D. Frederick, and A.S. Carr

2006 Assessment of archaeological site integrity in sandy substrates using luminescence dating. Bulletin of the Society for Archaeological Science 29(2):8-12. 
Bousman, C. B., M. B. Collins, P. Goldberg, T. Stafford, J. Guy, B. W. Baker, D. G. Steele, M. Kay, A. Kerr, G. Fredlund, P. Dering, V. Holliday, D. Wilson, W. Gose, S. Dial, P. Takac, R. Balinsky, M. Masson, and J. F. Powell 2002 The Palaeoindian-Archaic transition in North America: new evidence from Texas. Antiquity 76:980-990.

Brosowske, S. D. and R. Vehik

1999 Phase I and II Investigations at Impoundments 14 and 15A, Brushy-Peaceable Watershed, Pittsburg County, Oklahoma. Archaeological Research Report No. 17. Oklahoma Conservation Commission, Oklahoma City.

Coleman, R. E., M. Etchieson, T. K. Perttula, and S. Marceaux

2009 Ouachita National Forest: An Archeological Overview. Ouachita National Forest, Hot Springs, Arkansas.

Driskell, B. N. and R. B. Walker

2007 Making Sense of Paleoindian Subsistence Strategies. In Foragers of the Terminal Pleistocene in North America, edited by R. B. Walker and B. N. Driskell, pp. 226-237. University of Nebraska Press, Lincoln.

Ferring, C. R. (editor)

1994 Past Environments and Prehistory at McGee Creek Reservoir, Atoka County, Oklahoma. Volume V, Part 4 of the McGee Creek Archaeological Project Reports. Institute of Applied Sciences, University of North Texas, Denton.

Ferring, C. R., T. K. Perttula, P. McGuff, and B. C. Yates

1994a Prehistoric Archaeology at McGee Creek Reservoir, Atoka County, Oklahoma: Sites along McGee and Potapo Creeks and Tributaries. Volume V, Part 1 of the McGee Creek Archaeological Project Reports. Institute of Applied Sciences, University of North Texas, Denton.

1994b Archaeological Investigations at Four Sites along Potapo Creek, McGee Creek Reservoir, Atoka County, Oklahoma. Volume V, Part 3 of the McGee Creek Archaeological Project Reports. Institute of Applied Sciences, University of North Texas, Denton.

Frederick, C. D. and C. Ringstaff

1994 Lithic Resources at Fort Hood: Further Investigations. In Archeological Investigations on 571 Prehistoric Sites at Fort Hood, Bell and Coryell Counties, Texas, edited by W. N. Trierweiler, pp. 125-181. Archeological Resource Management Series Research Report No. 31. United States Army, Fort Hood, Texas.

Galm, J. R. and J. L. Hofman

1984 The Billy Ross Site: Analysis of a Dalton Component from the Southern Arkansas Basin in Eastern Oklahoma. Bulletin of the Oklahoma Anthropological Society 33:37-73.

Gettys, M.

1975 Preliminary Report on Archaeological Investigations at Lukfata Reservoir, Southeastern Oklahoma. General Survey Report No. 14. Oklahoma River Basin Survey, University of Oklahoma, Norman.

Goodyear, A. C.

1974 The Brand Site. Research Series No. 7. Arkansas Archeological Survey, Fayetteville.

Hackenberger, S. and A. Cheek

1976 Report of the Ten Percent Archaeological Reconnaissance of Proposed McGee Creek Reservoir. Research Report No. 4. Archaeological Research Associates, Tulsa.

Hofman, J. L., L. C. Todd, and M. B. Collins

1991 Identification of Central Texas Edwards Chert at the Folsom and Lindenmeier Sites. Plains Anthropologist 36:297-308.

Holloway, R. G.

1994 Ferndale Bog: A Record of Late Pleistocene-Holocene Climate and Vegetational Change. In Past Environments and Prehistory at McGee Creek Reservoir, Atoka County, Oklahoma, edited by C. R. Ferring, 
pp. 9-27. Volume V, Part 4 of the McGee Creek Archaeological Project Reports. Institute of Applied Sciences, University of North Texas.

Hughes, J. T. and P. S. Willey (editors)

1978 Archaeology at Mackenzie Reservoir. Archeological Survey Report No. 24. Office of the State Archeologist, Texas Historical Commission, Austin.

Jennings, T. A.

2008 San Patrice Technology and Mobility Across the Plains-Woodland Border. Memoir 12, Oklahoma Anthropological Society, and R. E. Bell Monographs in Anthropology, No. 5, Sam Noble Oklahoma Museum of Natural History, Norman.

Johnson, L., Jr.

1989 Great Plains Interlopers in the Eastern Woodlands during Late Paleo-Indian Times. Report No. 36. Office of the State Archeologist, Texas Historical Commission, Austin.

Lopinot, N. H., J. H. Ray, and M. D. Conner (editors)

1998 The 1997 Excavations at the Big Eddy Site (23CE426) in Southwest Missouri. Special Publication No. 2. Center for Archaeological Research, Southwest Missouri State University, Springfield.

2000 The 1999 Excavations at the Big Eddy Site (23CE426). Special Publication No. 3. Center for Archaeological Research, Southwest Missouri State University, Springfield.

2005 Regional Research and the Archaic Record at the Big Eddy Site (23CE426), Southwest Missouri. Special Publication No. 4. Center for Archaeological Research, Southwest Missouri State University, Springfield.

Lorrain, D. and N. Hoffrichter

1968 Archaeological Survey and Excavation at Pat Mayse Reservoir, Texas. Salvage Project, Southern Methodist University, Dallas.

Mallouf, R. J.

1976 Archeological Investigations at Proposed Big Pine Lake 1974-1975, Lamar and Red River Counties, Texas. Archeological Survey Report No. 18. Office of the State Archeologist, Texas Historical Commission, Austin.

McGuff, P. R.

1993 Testing of Archaeological Sites in the McGee Creek Project Area, Atoka County, Oklahoma. Volume II of the McGee Creek Archaeological Project Reports. Institute of Applied Sciences, University of North Texas, Denton.

McGuff, P. R., T. K. Perttula, and C. R. Ferring

1983 The McGee Creek Archaeological Project: An Interim Report. Institute of Applied Sciences, North Texas State University, Denton.

Morse, D. F.

1997 Sloan: A Paleoindian Dalton Cemetery in Arkansas. Smithsonian Institution Press, Washington, D. C.

Morse, D. F. and P. A. Morse

1983 Archaeology of the Central Mississippi Valley. Academic Press, New York.

Perino, G. and W. J. Bennett

1978 Archaeological Investigations at the Mahaffey Site, Ch-1, Hugo Reservoir, Choctaw County, Oklahoma. Museum of the Red River, Idabel, Oklahoma.

Perttula, T. K.

1984 Excavations at the Quince Site (34AT134), Atoka County, Oklahoma: An Interim Report. Newsletter of the Oklahoma Anthropological Society 32(3):2-6.

1985 The Quince Site: A Stratified Paleoindian to Woodland Occupation in the Ouachita Mountains of South- 
east Oklahoma. Current Research in the Pleistocene 2:25-26.

2007 Quince Site. In Encyclopedia of Oklahoma History and Culture. Oklahoma Historical Society. Online edition at http:digital.library.okstate.edu/encyclopedia.

2014 Hot Rock Cooking in Archaic and Woodland Period Sites in the Western Ouachita Mountains of Southeast Oklahoma. Bulletin of the Oklahoma Anthropological Society 61:79-106.

Perttula, T. K., with contributions by P. McGuff and C. R. Ferring

1994 Excavations at the Quince Site (34AT134), Atoka County, Oklahoma. Volume V, Part 2 of the McGee Creek Archaeological Project Reports. Institute of Applied Sciences, University of North Texas, Denton.

Perttula, T. K. and P. McGuff

1993 A Cultural Resources Survey of the McGee Creek Project Area, Atoka County, Oklahoma. Volume I of the McGee Creek Archaeological Project Reports. Institute of Applied Sciences, University of North Texas, Denton.

Perttula, T. K., C. R. Ferring, R. G. Holloway, and P. McGuff

1986 Past Environments and Paleoindian Occupations at McGee Creek, Southeast Oklahoma. Paper presented at the 7th Annual Meeting of the Mid-South Archaeological Conference, Natchez, Mississippi.

Perttula, T. K., P. McGuff, C. R. Ferring, and B. C. Yates

1983 McGee Creek Archaeology: A Consideration of Western Ouachita Mountains Prehistory. Bulletin of the Oklahoma Anthropological Society 32:23-54.

Ray, J. H., N. H. Lopinot, E. R. Hajic, and R. D. Mandel

1998 The Big Eddy Site: A Multicomponent Paleoindian Site on the Ozark Border, Southwest Missouri. Plains Anthropologist 43(163):73-81.

Redder, A. J.

1985 Horn Shelter Number 2: The South End: A Preliminary Report. Central Texas Archaeologist 10:27-65.

Reimer, P. J., M. G. L. Baillie, E. Bard, A. Bayliss, J. W. Beck, C. J. H. Bertrand, P. G. Blackwell, C. E. Buck, G.

S. Burr, K. B. Cutler, P. E. Damon, R. L. Edwards, R. G. Fairbanks, M. Friedrich, T. P. Guilderson, A. G. Hogg,

K. A. Hughen, B. Kromer, F. G. McCormac, S. W. Manning, C. B. Ramsey, R. W. Reimer, S. Remmele, J. R.

Southon, M. Stuiver, S. Talamo, F. W. Taylor, J. van der Plicht, and C. E. Weyhenmeyer

2004 IntCal04 Terrestrial Radiocarbon Age Calibration, 26-0 ka BP. Radiocarbon 46:1029-1058.

Rohrbaugh, C. L.

1972 Hugo Reservoir II: A Discussion of the Development of the Archaic Cultures in Hugo Reservoir into the Pre-Formative and Formative Tradition and Including the Descriptions of Three Archaic Sites dug during the 1970 Field Season: Ch-89, The McKensie site; Pu-58, The Hill Site; and Ch-113A, The Pat Boyd Place, Area A. Archaeological Site Report No. 23. Oklahoma River Basin Survey Project, University of Oklahoma, Norman.

Rohrbaugh, C. L., R. J. Burton, S. S. Burton, and L. J. Rosewitz

1971 Hugo Reservoir I. Archaeological Site Report No. 22. Oklahoma River Basin Survey Project, University of Oklahoma, Norman.

Story, D. A.

1990 Cultural History of the Native Americans. In The Archeology and Bioarcheology of the Gulf Coastal Plain, by D. A. Story, J. A. Guy, B. A. Burnett, M. D. Freeman, J. C. Rose, D. G. Steele, B. W. Olive, and K. J. Reinhard, pp. 163-366. 2 Vols. Research Series No. 38. Arkansas Archeological Survey, Fayetteville.

Sundermeyer, S. A., T. G. Baugh, J. Whaley, and M. L. McMinn

2004 Cultural Resource Investigations of 11 Archaeological Sites at Broken Bow Reservoir, McCurtain County, Oklahoma. Miscellaneous Reports, Report of Investigations No. 5. LopezGarcia Group, Dallas. 
Thoms, A. V.

2008 The fire stones carry: Ethnographic records and archaeological expectations for hot-rock cookery in western North America. Journal of Anthropological Archaeology 27(4):443-460.

Wyckoff, D. G.

1967a The Archaeological Sequence of the Broken Bow Reservoir Area, McCurtain County, Southeast Oklahoma. Stovall Museum of Natural History, University of Oklahoma River basin Survey, and University of Oklahoma Research Institute, Norman.

1967b Woods Mound Group: A Prehistoric Mound Complex in McCurtain County, Oklahoma. Bulletin of the Oklahoma Anthropological Society 15:1-76.

1968 The Bell and Gregory Sites: Archaeological Chronicles of Prehistory in the Pine Creek Reservoir Area, Southeast Oklahoma. Archaeological Site Report No. 11. Oklahoma River Basin Survey, University of Oklahoma, Norman.

1984 The Foragers: Eastern Oklahoma. In Prehistory of Oklahoma, edited by R. E. Bell, pp. 119-160. Academic Press, New York.

1985 The Packard Complex: Early Archaic, Pre-Dalton Occupations on the Prairie-Woodlands Border. Southeastern Archaeology 4:1-26.

1989 Accelerator Dates and Chronology at the Packard Site, Oklahoma. Current Research in the Pleistocene 6:24-26.

1999 Southern Plains Folsom Lithic Technology: A View from the Edge. In Folsom Lithic Technology: Explorations in Structure and Variation, edited by D. S. Amick, pp. 39-64. Archaeological Series 12. International Monographs in Prehistory, Ann Arbor, Michigan.

2005a A Site (34PU101) near Holly Creek: Clues to Early Holocene Occupations in the Ouachita Mountains. Oklahoma Archeology 53(4):29-40.

2005b Recent Lithic Technological Studies on the Southern Plains and Adjacent regions, Part I: Identifying and Sourcing Raw Materials. Lithic Technology 30(2):89-105.

Wyckoff, D. G. and R. Bartlett

1995 Living on the Edge: Late Pleistocene-Early Holocene Cultural Interaction along the Southeastern Woodlands-Plains Border. In Native American Interactions: Multiscalar Analyses and Interpretations in the Eastern Woodlands, edited by M. S. Nassaney and K. S. Sassaman, pp. 27-72. University of Tennessee Press, Knoxville. 